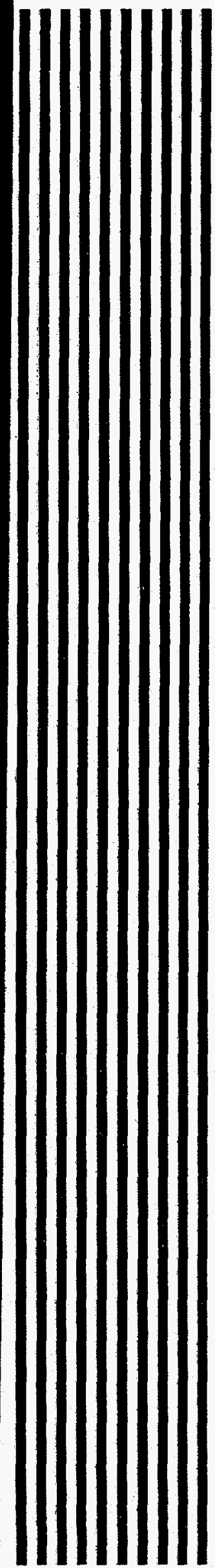

DOE/EA-1246

\title{
ENVIRONMENTAL ASSESSMENT \\ FOR THE \\ A-01 OUTFALL CONSTRUCTED \\ WETLANDS PROJECT \\ AT THE
}

SAVANNAH RIVER SITE

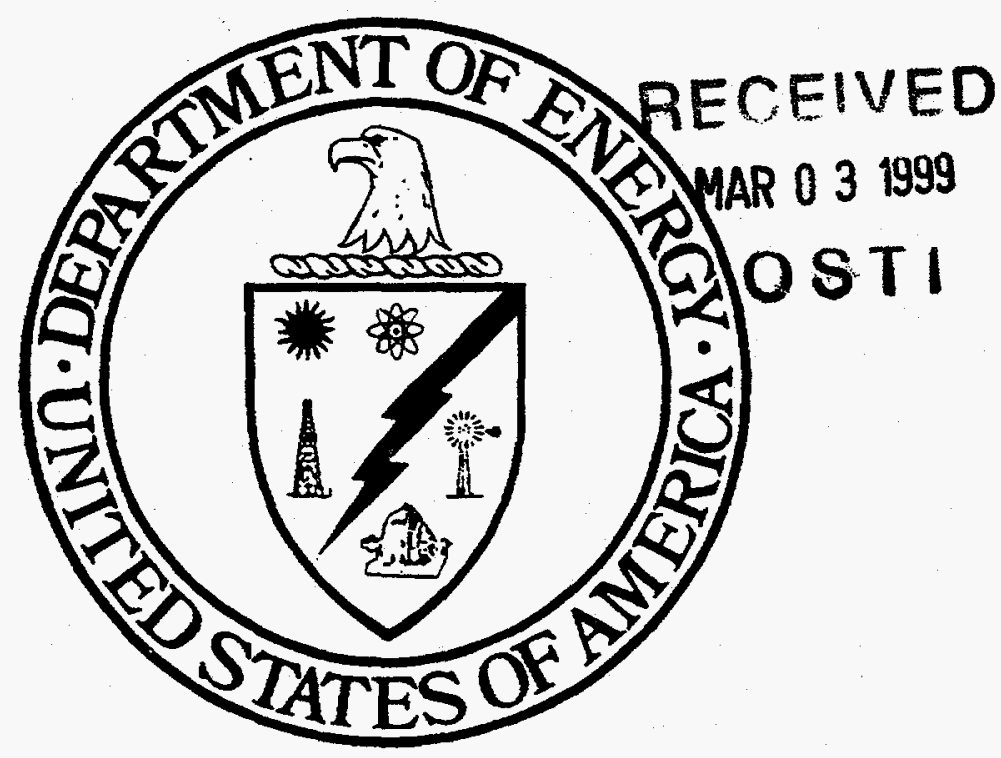

OCTOBER 1998

DISTRISUTION OF THIS DOCUMENT is UNLIATIED N MASTER

U. S. DEPARTMENT OF ENERGY

SAVANNAH RIVER OPERATIONS OFFICE

SAVANNAH RIVER SITE 


\section{DISCLAMMER}

This report was prepared as an account of work sponsored by an agency of the United States Government. Neither the United States Government nor any agency thereof, nor any of their employees, makes any warranty, express or implied, or assumes any legal liability or responsibility for the accuracy, completeness. or usefulness of any information, apparatus, product, or process disclosed. or represents that its use would not infringe privately owned rights. Reference berein to any specific commercial product, process, or service by trade name, trademaric inanufacturer, or otherwise does not necessarily constitute or imply its endorsement recommendation, or favoring by the Uaited States Government or any ageacy thereof. The views and opinions of authors expressed herein do not necessarily state or reflect those of the United States Government or any agency thercof. 


\section{DISCLAIMER}

Portions of this document may be illegible in electronic image products. Images are produced from the best available original document. 


\section{Finding of No Significant Impact \\ and \\ Floodplain Statement of Findings}

A-01 Outfall Constructed Wetlands Project 2FCEIVED at the Savannah River Site

Agency: U. S. Department of Energy

MAR 031999

Action: Finding of No Significant Impact

Summary: The Department of Energy (DOE) has prepared an environmental assessment (EA) (DOE/EA-1246) for the proposed A-01 outfall constructed wetlands project at the Savannah River Site (SRS), located near Aiken, South Carolina. Based on the analyses in the EA, DOE has determined that the proposed action is not a major Federal action significantly affecting the quality of the human environment within the meaning of the National Environmental Policy Act of 1969 (NEPA). Therefore, the preparation of an environmental impact statement (EIS) is not required, and DOE is issuing this Finding of No Significant Impact (FONSI) and Floodplain Statement of Findings.

Public Availability: Copies of the EA and FONSI or further information on the DOE NEPA process are available from:

Andrew R. Grainger

NEPA Compliance Officer

Savannah River Operations Office

Bldg. 773-42A/Room 212

Aiken, South Carolina 29808

Phone/FAX: (800) 881-7292

E-mail: nepa@srs.gov

Background: On August 6, 1996, the South Carolina Department of Health and Environmental Control (SCDHEC) issued a new National Pollutant Discharge Elimination System (NPDES) permit for SRS, which became effective October 1, 1996. In the new permit, SCDHEC moved the A-01 outfall to consolidate several outfalls and established suspended (i.e., temporarily postponed) limits for copper, lead, mercury, and chronic toxicity. Limits had not been specified for these effluent constituents in the previous NPDES permit. A testing requirement for total residual chlorine at the A-01 outfall further resulted in a permit modification, effective January 1, 1998, establishing a new suspended limit for that parameter as well. All of these new limits will go into effect no later than October 1, 1999.

Subsequent to SCDHEC issuing the new permit, samples taken at the relocated A-01 outfall have shown that the effluent consistently does not meet the new outfall limits for both copper and chronic toxicity. Laboratory testing has traced the chronic toxicity back to the elevated copper levels in the effluent. An investigation, conducted to determine the source of the copper, established that building service piping draining to the outfall was the primary source of the copper problem. Steam and air conditioning condensates were also identified as significant contributors by a later study. A collective effluent volume of approximately 3.4 million liters per day [0.9 million gallons per day] is currently discharged at the A-01 outfall NPDES compliance sampling point.

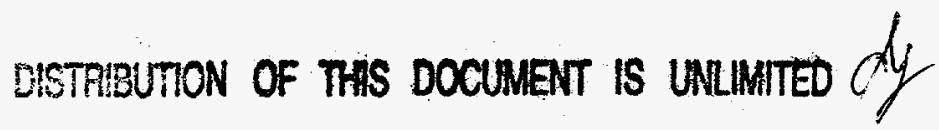


The new SRS NPDES permit specifies that SRS must conduct an investigation of the discharges at the A-01 outfall to determine how compliance with the new limits would be achieved. Extensive research has indicated that an artificial subsurface flow wetlands would treat these constituents and reduce the concentrations below the new permit limits before the effluent reaches the NPDES compliance sampling point. Therefore, DOE has decided to propose the implementation of this type of constructed wetlands as an alternative to enable compliance with these new regulatory requirements at SRS.

Purpose and Need for Action: The purpose for action is to reduce the effluent concentrations of copper and chronic toxicity before October 1, 1999, when the new NPDES outfall limits are scheduled to go into effect. DOE needs to implement the action to reduce these concentrations to enable compliance with the SRS NPDES permit and prevent the potential issuance of a violation for failure to meet the new outfall limits.

Proposed Action: The proposed action entails the construction and operation of the following: (1) a system of pipes to collect the process and storm water effluent from the local outfalls, (2) a process water flow equalization basin and artificial subsurface flow wetiand cell complex to treat the effluent from these outfails, and (3) an outlet system to discharge the treated effluent into Tim's Branch, the previously-established onsite receiving stream for the subject outfalls. In addition, the A-01-sampling point monitored by both SRS and SCDHEC would be relocated from the current location to a new site below the present outfall structure prior to the effluent flow entering the waters of the State. Construction of the proposed action would be scheduled to begin in early 1999, with facility operations commencing as early as September 1999. The total estimated cost of the proposed action is approximately $\$ 4,900,000$.

The collection of the process and storm water effluent from the local outfalls would be accomplished through a system of pipes. This system would consist of a main pipeline extending from the A-1AA outfall under the parking lot adjacent to the Savannah River Technology Center to the wetlands/detention basin complex located to the west of A Area. Along the main pipeline route, tie-in pipes would be installed to connect the other local outfalls to the collection system. Any existing piping associated with these outfalls, which would be bypassed by the new collection system, would be abandoned in place.

The process water flow equalization basin would be located in the confluence of the two existing drainage features located to the west and north of the SREL graveled access road. The basin would impound an area of approximately 0.8-2.0 hectares (2-5 acres) in size behind the earthen berm supporting the adjacent roadway. Minimal site clearing and grading would be required during the construction of this impounded area. The capacity of the basin, controlled by a standpipe structure discharging into the existing culvert, would be designed for approximately 3.8 million liters (1.0 million gallons). Piping similar to that used for the collection system would then be installed to enable a gravity-feed of this impounded water into the wetland cell facility. Excess runoff produced by storm events would be discharged down the standpipe and through the culvert into Tim's Branch. An ongoing SRS project to identify and reduce copper in stormwater runoff within SRTC should achieve compliance levels of this parameter in the downgradient waters of the State during such storm events. Should these efforts not result in the necessary source reduction of copper, additional stormwater detention capacity would be constructed adjacent to the wetland cells facility. In the event that this decision to construct additional stormwater capacity is reached, the process water flow equalization basin would not be constructed, and a stormwater detention basin (i.e., design basis to contain a 25-year/24-hour storm event) would be incorporated into the proposed project scope at the additional cost of approximately $\$ 500,000$ above the 
current project estimate. The project's pipeline collection system would also be rerouted to discharge directly into this stormwater detention basin.

The subsurface flow wetland cell facility would be built in an undeveloped area located to the southeast of the SREL graveled access road. The footprint of the proposed facility would encompass approximately 6.1-6.5 hectares (15-16 acres) of currently undeveloped lands. The constructed wetland cell facility would be permitted as an industrial wastewater treatment facility by SCDHEC. This facility would consist of a series of interconnected artificial wetland cells to treat the outfall effluent. The gavity-fed pipeline from the equalization basin would discharge directly into a small receiving basin at the edge of the facility. From the receiving basin, the effluent would be distributed into and filtered through the wetlands to an outlet collection system. The treated effluent would then be piped to the new outfall discharge structure on Tim's Branch. Should additional stormwater capacity be required, it would both physically and functionally replace the small receiving basin within the process flow through this facility.

The wetland cells would be excavated, surrounded by earthen containment berms, and lined to preveni any seepage into the surrounding environment. The liner would consist of a geomembrane liner and/or a soil liner. The geomembrane material would be-selected to be able to withstand loads imposed during construction activities. A layer of filter media capable of reducing the effluent constituents would be placed on the bottoms of the wetland cells. The surface area required, depth of media, and flow characteristics through the media would be determined at a later date. Aquatic floral species may be planted in the wetland cells as an additional measure to control erosion and enhance metal-removal efficiencies.

The last portion of the proposed action would be the construction of the discharge pipeline and outfall structure. This activity would entail placement of an outflow pipe from the wetland cell facility downslope to the area adjacent to Tim's Branch, construction of an outfall structure on the margin of the stream channel, and placement of riprap within the streambed. The location of the proposed new outfall would be on the south side of the Tim's Branch stream corridor. The pipeline right-of-way would be cleared. A temporary access road for construction vehicles would also be built within that right-of-way. The pipeline would either be routed above grade on support pillars or below grade until it reaches the outfall structure. The outfall structure would consist of a concrete headwall supporting the discharge pipe above the receiving stream. Large riprap would be placed within the streambed of Tim's Branch at the outfall location to prevent erosion and scouring by the discharged effluent.

Best management practices would be employed during construction and maintenance activities associated with this proposed action. Specific erosion control and storm water management practices would be employed to ensure there is no deposition of erosional material or sediment into the downslope wetland areas during construction. A number of mitigation activities would be implemented to minimize potential impacts to the floodplain and wetlands. Operation of construction equipment in the wetland and floodplain areas would be minimized. Silt fences and other erosion control structures as needed would be installed to ensure there is no deposition in the downslope wetland areas. An erosion control plan would be developed so that the proposed action complies with applicable State and local floodplain protection standards and further to ensure that no additional impacts to wetlands will occur due to erosion and sedimentation.

Alternatives: In accordance with NEPA regulations, DOE examined the following alternatives to the proposed action: (1) no action, continue to use the existing outfalls; (2) install a pipeline to discharge directly into Upper Three Runs; (3) build a full-scale ion 
exchange facility; and (4) relocate the A-01 outfall and use an existing wetlands area. With respect to selecting the alternative to take no action, this would consist of SRS continuing to use the existing outfalls that contribute to the A-01 effluent. The contaminant levels in this effluent would remain unchanged, and would therefore continue to exceed the new outfall limits for copper and chronic toxicity. Selection of this alternative would result in the site being in violation of the new limits when these go into effect next year.

The alternative to install a pipeline collection system to discharge directly into Upper Three Runs would entail the placement of approximately $5.3 \mathrm{~km}(3.3 \mathrm{mi})$ of underground pipeline sited over uneven terrain and through variable habitats. Almost the entire length of the proposed pipeline route would be through undeveloped portions of SRS. Although this alternative would result in an outfall which would be in compliance, it would also be very expensive and result in more environmental impacts as compared to implementing the proposed action.

A third alternative would be to construct a full-scale ion exchange facility to collect and treat the A-01 effluent streams. The scope of this alternative would be to place multiple skid-mounted ion exchange units designed for the flow rates at the A-01 outfall. Each unit is a highly-integrated and fully-automatic system which features a buffer tank, $\mathrm{pH}$ control, pumping system, media filter, ion exchange columns, resin, modular valve systems, and an overall control system. The ion exchange system could operate continuously. Although technically feasible, this alternative would be more complex and costly compared to the proposed action. The total estimated cost (i.e., $\$ 3.3$ million) does not include the required retention basin designed for a 25 -year storm event.

The last alternative would consist of relocating the A-01 outfall further downstream in Tim's Branch in an area below existing emergent marsh wetlands situated within the stream channel and impounded by a culverted road crossing. This portion of Tim's Branch has already realized the benefit of some treatment in the form of streambed soils naturally binding metals out of the stream effluent because of both the downstream location and the reduced-flow impounded conditions. The result is a reduced level of copper in the effluent being discharged through the culvert pipe draining the impounded area. This alternative, therefore, would take advantage of a naturally-occurring process to achieve compliance with the new limits. The cost of implementing this alternative would be small and the implementation time would be short. However, subsequent discussion of this alternative with SCDHEC identified this impounded area as waters of the State. SCDHEC further stated that treatment of the A-01 outfall effluent would have to take place before reaching any waters of the State. Except for relocating the NPDES sampling location further downstream, implementation of this alternative would be effectively the same as that of the no-action alternative.

Environmental Impacts: The principal cumulative impacts from the proposed action would be those effects associated with the loss of 0.013 percent of site forested habitat for timber management and the similar loss of 0.009 percent of SRS lands available for environmental/ecological research. There would be no measurable impact on the local economy as a result of the proposed action. Some individual mortality of wildlife species and a less than 0.005 percent loss of available wildlife habitat on SRS would result with the construction of the proposed wastewater treatment facility. The proposed facility would have no adverse impacts on threatened and endangered species or cultural resources. The impacts to 100-year floodplain and jurisdictional wetlands would be minor. Cumulative ambient air quality impacts would be negligible. Assuming that both protective clothing and adequate safety measures are utilized, the proposed action should not pose any potential problems for either human health or worker safety. There would 
be no measurable impact to either public health or safety as a consequence of the proposed action. Negligible traffic and transportation impacts would result from implementation of the proposed action. No adverse impacts to either surface or groundwater quality would be expected from the operation of the proposed action. The surface water quality in Tim's Branch would improve following operational start-up of the proposed facility.

Floodplain Statement of Findings: This is a Floodplain Statement of Findings prepared in accordance with 10 CFR Part 1022. A Floodplain/Wetlands Assessment was prepared for the area to be impacted by the installation of the proposed outfall structure in Tim's Branch. The Floodplain/Wetlands Assessment stated that both 100-year floodplain and wetlands did exist at the project location. Project plans at this location were developed in such a manner as to minimize the potential impacts on the floodplain and wetlands at SRS. Only the last few meters/yards of this pipeline would be within the 100 -year floodplain. The outfall structure would consist of a concrete headwall supporting the discharge pipe above the receiving stream. Large riprap would be placed within the wetlands of Tim's Branch at the outfall location to prevent erosion and scouring by the discharged effuent. The area impacted by the placement of this riprap would encompass less than 5.00 square meters (5.98 square yards). The proposed activities associated with installing a new outfall structure are expected to fall under a Section 404 Nationwide Permit. Additionally, an erosion control plan will be developed in accordance with applicable state and local floodplain protection standards and followed to ensure that no additional impacts to wetlands will occur due to erosion and sedimentation. Best management practices will be employed during construction and maintenance activities.

Determination: Based on the information and analyses in the EA (DOE/EA-1246), and after careful consideration of all comments, DOE has determined that implementing the proposed A-01 outfall constructed wetlands project at SRS does not constitute a major Federal action significantly affecting the quality of the human environment within the meaning of NEPA. Therefore, an EIS is not required and DOE is issuing this FONSI and Floodplain Statement of Findings.

Signed in Aiken, South Carolina, this $7 \stackrel{t h}{=}$ day of $8 \mathrm{~A}, 1998$.

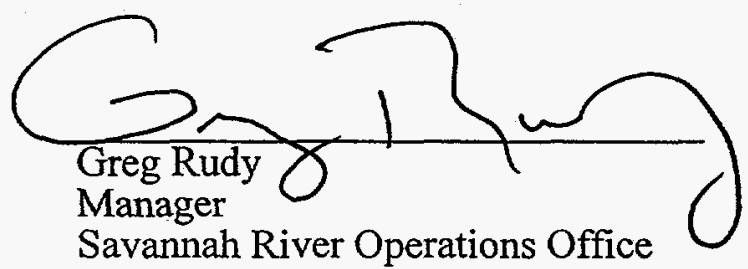


DOE/EA-1246

\section{ENVIRONMENTAL ASSESSMENT \\ FOR THE \\ A-01 OUTFALL CONSTRUCTED \\ WETLANDS PROJECT \\ AT THE \\ SAVANNAH RIVER SITE}

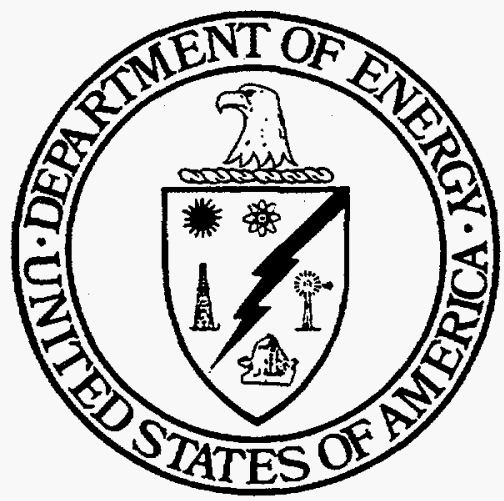

OCTOBER 1998

U. S. DEPARTMENT OF ENERGY

SAVANNAH RIVER OPERATIONS OFFICE

SAVANNAH RIVER SITE 
This page is intentionally left blank 


\section{TABLE OF CONTENTS}

1.0 INTRODUCTION

1.1 Background

1.2 Purpose and Need for Action

$2.0 \quad$ PROPOSED ACTION AND ALTERNATIVES 4

2.1 Proposed Action

2.2 Alternatives to the Proposed Action

2.2.1 No Action, Continue to Use the Existing Outfalls 10

2.2.2 Install a Pipeline to Discharge Directly into Upper Three Runs 10

2.2.3 Build a Full-Scale Ion Exchange Facility 10

2.2.4 Relocate the A-01 Outfall and Use an Existing Wetland Area

3.0 AFFECTED ENVIRONMENT

3.1 Land Use

3.2 Geology and Seismology 11

3.3 Hydrology

12

3.4 Ecological and Cultural Resources

3.5 Radiation Environment

4.0 ENVIRONMENTAL CONSEQUENCES OF THE PROPOSED ACTION AND ALTERNATIVES

4.1 Project Construction 15

4.2 Normal Operation 18

4.3 Accident Analysis 20

4.4 Environmental Consequences of the Alternatives 20

4.5 Cumulative Impacts 21

5.0 REGULATORY AND PERMITTING PROVISIONS CONSIDERED

5.1 National Environmental Policy Act of 1969, as amended (42 USC 4321 et seq.) 22

5.2 Solid Waste Regulations 22

5.3 Air Emissions Regulations 22

5.4 Liquid Discharge Regulations 22 


\section{LIST OF TABLES}

Table 1-1. Comparison of the new NPDES outfall limits and the effluent concentrations for these constituents observed at the A-01 outfall.

\section{LIST OF FIGURES}

Figure 1-1. Location of the A-01 Outfall Constructed Wetlands Project at the Savannah River Site, South Carolina.

Figure 2-1. Schematic diagram of the current layout compared to that of the proposed A-01 Outfall Constructed Wetlands Project.

Figure 2-2. Conceptual area layout of the proposed A-01 Outfall Constructed Wetlands Project.

\section{APPENDICES}

Appendix A: Floodplain/Wetland Assessment for the A-01 Outfall Constructed Wetlands Project at the Savannah River Site

Appendix B: Response to Public Comments 


\section{LIST OF ABBREVIATIONS/ACRONYMS}

The following is an alphabetized list of the abbreviations and acronyms found within the text of this document:

$\begin{array}{ll}\text { CFR } & \text { - Code of Federal Regulations } \\ \text { DOE } & - \text { U. S. Department of Energy } \\ \mathrm{cm} & - \text { centimeter } \\ \text { EA } & - \text { Environmental Assessment } \\ \text { EIS } & - \text { Environmental Impact Statement } \\ \mathrm{ft} & - \text { feet } \\ \text { gpd } & - \text { gallons per day } \\ \text { HNUS } & - \text { Halliburton NUS Corporation } \\ \text { in } & - \text { inch } \\ \text { km } & - \text { kilometers } \\ \mathrm{m} & - \text { meter } \\ \text { mg/l } & - \text { milligrams per liter } \\ \text { mi } & - \text { miles } \\ \mu \text { g/l } & - \text { micrograms per liter } \\ \text { mrem } & - \text { 1/1000 roentgen equivalent man } \\ \text { NEPA } & - \text { National Environmental Policy Act } \\ \text { NPDES } & - \text { National Pollutant Discharge Elimination System } \\ \text { NUS } & - \text { NUS Corporation } \\ \text { OSHA } & - \text { Occupational Safety and Health Act } \\ \text { SC } & - \text { South Carolina } \\ \text { SCDHEC } & - \text { South Carolina Department of Health and Environmental Control } \\ \text { sec } & - \text { second } \\ \text { SMIX } & - \text { skid-mounted ion exchange } \\ \text { SR } & - \text { Savannah River Operations Office } \\ \text { SRARP } & - \text { Savannah River Archaeological Research Program } \\ \text { SREL } & - \text { Savannah River Ecology Laboratory } \\ \text { SRI } & - \text { Savannah River Natural Resource Management and Research } \\ & \text { Institute } \\ \text { SRL } & - \text { Savannah River Laboratory } \\ \text { SRS } & - \text { Savannah River Site } \\ \text { SRTC } & - \text { Savannah River Technology Center } \\ \text { USC } & - \text { United States Code } \\ \text { USGS } & - \text { U. S. Geological Survey } \\ \text { WSRC } & - \text { Westinghouse Savannah River Company } \\ & \end{array}$


This page is intentionally left blank 


\subsection{INTRODUCTION}

The Department of Energy (DOE) prepared this environmental assessment (EA) to analyze the potential environmental impacts associated with the proposed A-01 outfall constructed wetlands project at the Savannah River Site (SRS), located near Aiken, South Carolina (Figure 1-1). The proposed action would include the construction and operation of an artificial wetland to treat effluent from the A-01 outfall located in A Area at SRS. The proposed action would reduce the outfall effluent concentrations in order to meet future outfall limits before these go into effect on October 1, 1999.

This document was prepared in compliance with the National Environmental Policy Act (NEPA) of 1969, as amended; the requirements of the Council on Environmental Quality Regulations for Implementing NEPA (40 CFR Parts 1500-1508); and the DOE Regulations for Implementing NEPA (10 CFR Part 1021). NEPA requires the assessment of environmental consequences of Federal actions that may affect the quality of the human environment. Based on the potential for impacts described herein, DOE will either publish a Finding of No Significant Impact or prepare an environmental impact statement (EIS).

\subsection{Background}

On August 6, 1996, the South Carolina Department of Health and Environmental Control (SCDHEC) issued a new National Pollutant Discharge Elimination System (NPDES) permit (SC0000175) for SRS, which became effective October 1, 1996. In the new permit, SCDHEC moved the A-01 outfall to consolidate several outfalls and established suspended (i.e., temporarily postponed) limits for copper, lead, mercury, and chronic toxicity. Limits had not been specified for these effluent constituents in the previous NPDES permit. A testing requirement for total residual chlorine at the A-01 outfall further resulted in a permit modification, effective January 1, 1998, establishing a new suspended limit for that parameter as well. All of these new limits will go into effect no later than October 1, 1999.

Subsequent to SCDHEC issuing the new permit, samples taken at the relocated A-01 outfall (Figure 1-1) have shown that the effluent consistently does not meet the new outfall limits for both copper and chronic toxicity (Table 1-1). Laboratory testing has traced the chronic toxicity back to the elevated copper levels in the effluent. An investigation was conducted to determine the source of the copper. The results of this effort established that building service piping draining to the outfall was the primary source of the copper problem (Broaden 1996). Steam and air conditioning condensates were also identified as significant contributors by a later study (WSRC 1997). A collective effluent volume of approximately 3.4 million liters per day [0.9 million gallons per day (gpd)] is currently discharged at the NPDES compliance sampling point. 


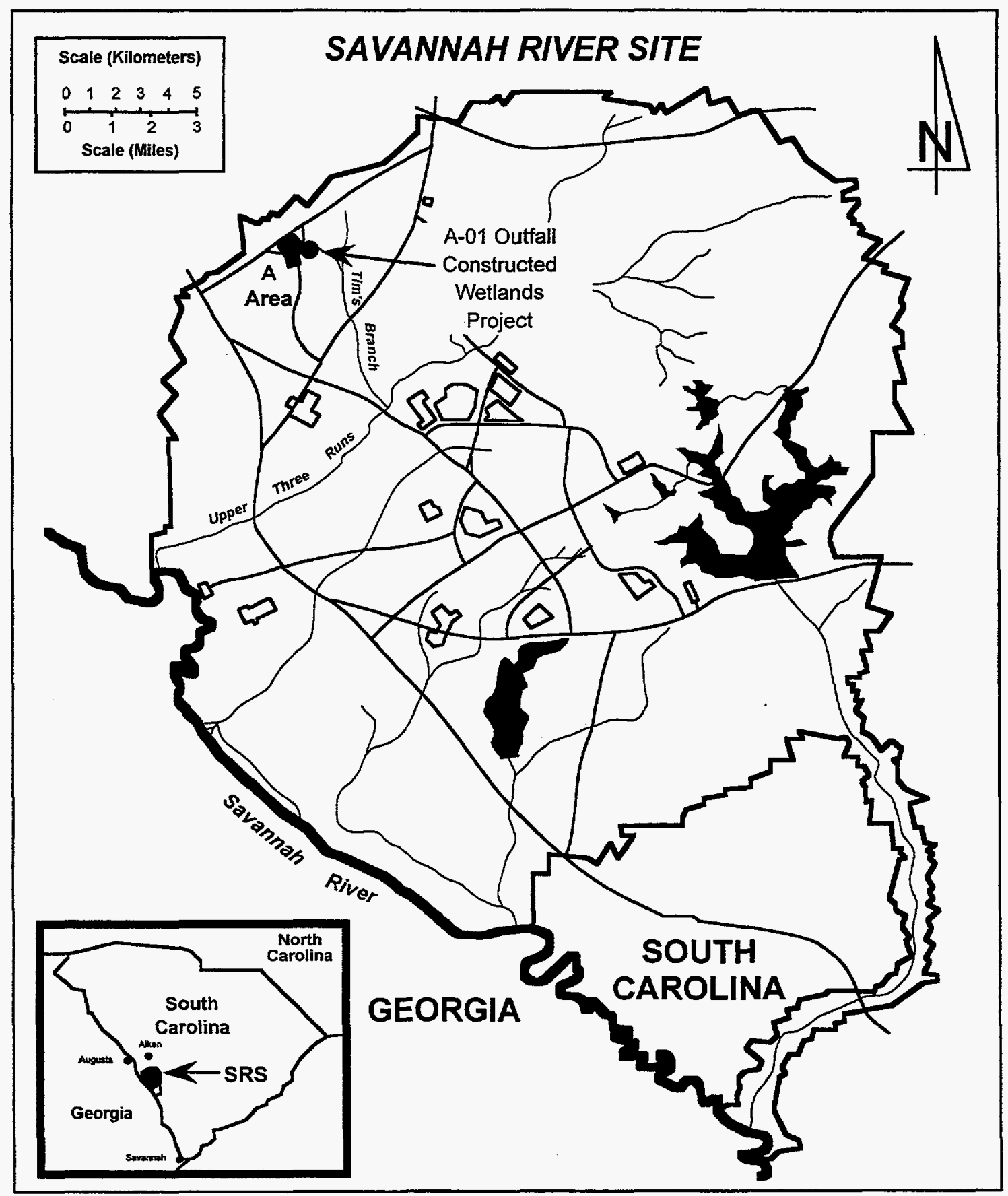

Figure 1-1. Location of the A-01 Outfall Constructed Wetlands Project at the Savannah River Site, South Carolina. 
Table 1-1. Comparison of the new NPDES outfall limits and the effluent concentrations for these constituents observed at the A-01 outfall.

\begin{tabular}{cccc}
\hline \hline $\begin{array}{c}\text { Effluent } \\
\text { Constituents }\end{array}$ & NPDES Limit a & $\begin{array}{c}\text { A-01 Outfall } \\
\text { Maximum } \\
\text { Observed } \\
\text { Concentrations }\end{array}$ & $\begin{array}{c}\text { Long Term } \\
\text { Average }\end{array}$ \\
\hline Copper & $0.022 \mathrm{mg} / 1$ & $0.308 \mathrm{mg} / \mathrm{c}^{\mathrm{c}}$ & $0.042 \mathrm{mg} / \mathrm{l}^{\mathrm{c}}$ \\
Lead & $0.005 \mathrm{mg} / 1$ & $0.021 \mathrm{mg} / \mathrm{l}^{\mathrm{c}}$ & $<0.003 \mathrm{mg} / \mathrm{l}^{\mathrm{c}}$ \\
Mercury & $0.013 \mu \mathrm{g} / 1$ & $0.20 \mu \mathrm{g} / \mathrm{l}^{\mathrm{c}}$ & $<0.10 \mu \mathrm{g} / \mathrm{l}^{\mathrm{d}}$ \\
$\begin{array}{c}\text { Total Residual } \\
\text { Chlorine }\end{array}$ & $0.012 \mathrm{mg} / 1$ & $0.14 \mathrm{mg} / \mathrm{l}^{\mathrm{c}}$ & $<0.05 \mathrm{mg} / \mathrm{l}^{\mathrm{c}}$ \\
Chronic Toxicity & Pass b & Fail $\mathrm{e}$ & Fail $\mathrm{f}$ \\
\hline
\end{tabular}

a New monthly average NPDES permit limit scheduled to become effective on October 1, 1999

b Zero failures at an instream waste concentration of $93.4 \%$

c Based on Dukes (1997)

d Based on Payne (1998)

e A total of 13 failures between October 1, 1996 and September 30, 1997

(Source: Monthly Discharge Monitoring Reports)

f Based on Monthly Discharge Monitoring Reports 
The new SRS NPDES permit specifies that SRS must conduct an investigation of the discharges at the A-01 outfall to determine how compliance with the new limits would be achieved. Extensive research has indicated that an artificial subsurface flow wetland would treat these constituents (Kadlec and Knight 1996) and reduce the concentrations below the new permit limits before the effluent reaches the NPDES compliance sampling point. Therefore, DOE has decided to propose the implementation of this type of constructed wetlands as an alternative to enable compliance with these new regulatory requirements at SRS.

\subsection{Purpose and Need for Action}

The purpose for action is to reduce the effluent concentrations of copper and chronic toxicity before October 1, 1999, when the new NPDES outfall limits are scheduled to go into effect. DOE needs to implement the action to reduce these concentrations to enable compliance with the SRS NPDES permit and prevent the potential issuance of a violation for failure to meet the new outfall limits.

\subsection{PROPOSED ACTION AND ALTERNATIVES}

\subsection{Proposed Action}

The proposed action entails the construction and operation of the following: (1) a system of pipes to collect the process and storm water effluent from the local outfalls (i.e., A-1AA, A-1B, A-1C, A-03, A-04, and A-05), (2) a process water flow equalization basin and artificial subsurface flow wetland cell facility to treat the effluent from these outfalls, and (3) an outlet system to discharge the treated effluent into Tim's Branch, the previously-established onsite receiving stream for the subject outfalls (See Figures 2-1 and 2-2). In addition, the A-01 sampling point monitored by both SRS and SCDHEC would be relocated from the current location to a new site below the present outfall structure prior to the effluent flow entering the waters of the State. Construction of the proposed action would be scheduled to begin in early 1999, with facility operations commencing as early as September 1999. The total estimated cost of the proposed action is approximately $\$ 4,900,000$.

Sampling of all flows contributing to the current A-01 outfall effluent (Figure 2-1) has shown that the A-1A outfall (i.e., discharged from the SRTC A-2 airstripper) is the only source consistently meeting the new outfall limits for copper and chronic toxicity. Therefore, no treatment would be required for the A-1A effluent which is already permitted separately from the other local outfalls. Adding the A-1A discharge flow to that of the other outfall effluents within the pipeline collection system would also increase that portion of the project costs. Because of this, the A-1A outfall would be maintained in the proposed action as it currently exists, discharging into Tim's Branch adjacent to SRS Road A-1 (Figure 2-2). 


\section{Current Layout}

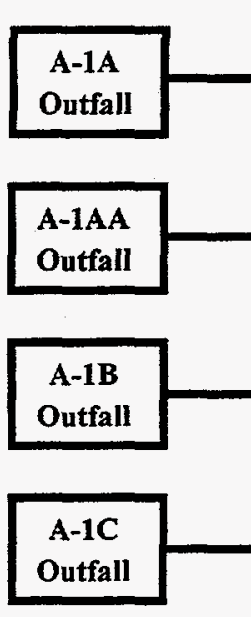

A-01 Outfall

NPDES Compliance

Sampling Point

\section{Old A-01}

Outfall
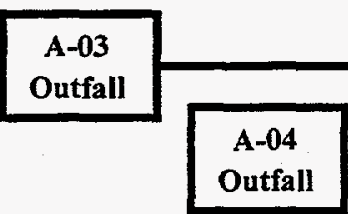

A-05

Outfall

\section{NOT TO SCALE}

Proposed Action

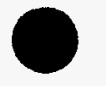

A-01 Outfall

NPDES Compliance

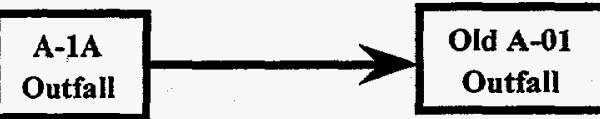

Sampling Point

\section{A-1AA \\ Outfall}

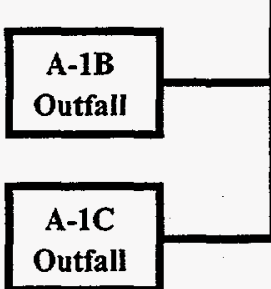

\section{A-03 \\ Outfall}

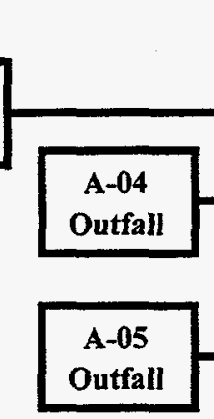

NOT TO SCALE

Figure 2-1. Schematic diagram of the current layout compared to that of the proposed A-01 Outfall Constructed Wetlands Project. 


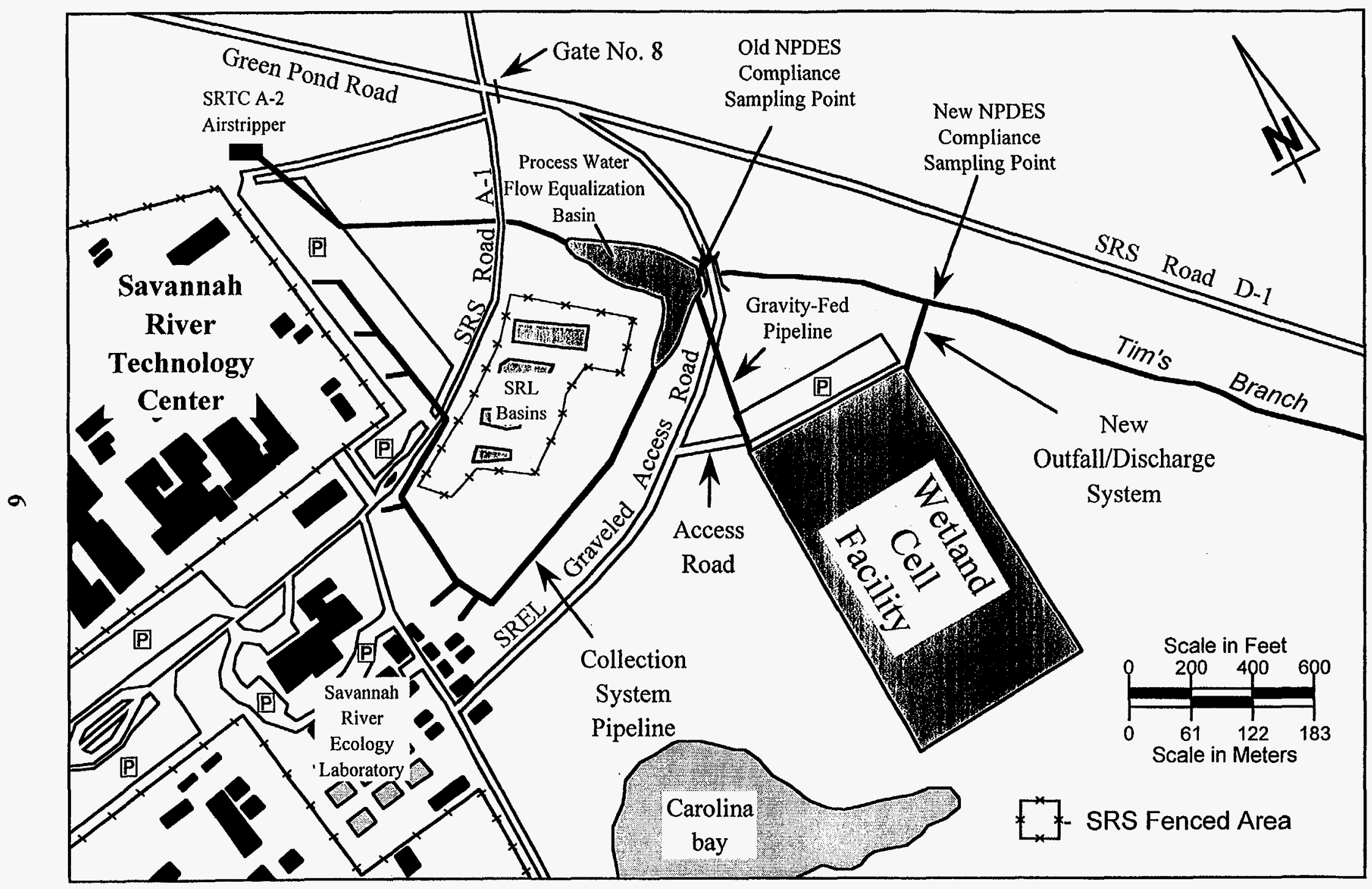

Figure 2-2. Conceptual area layout of the proposed A-01 Outfall Constructed Wetlands Project. 
The collection of the process and some storm water effluent from these outfalls would be accomplished through a system of pipes. This system would consist of a main pipeline extending from the A-1AA outfall under the parking lot adjacent to the Savannah River Technology Center (SRTC), down the length of that parking lot, under SRS Road A-1, around the Savannah River Laboratory (SRL) Basins, along the northern periphery the Savannah River Ecology Laboratory (SREL) graveled access road, and finally into the proposed process water flow equalization basin located in the area of the present NPDES compliance sampling point. Along the main pipeline route, tie-in pipes would be installed to connect the remainder of the outfalls to the collection system (Figure 2-1). The collection system piping would be of standard construction (e.g., either concrete or metal) and placed approximately 1.2-6.1 meters (4-20 feet) below grade. Any existing piping associated with these outfalls, which would be bypassed by the new collection system, would be abandoned in place. The new piping to be placed under SRS Road A-1 would be designed to adequate load-bearing criteria as required by site traffic needs. Temporary construction access roads along the undeveloped portions of the pipeline route would be required during construction. Following installation and backfilling of the pipeline, these previously-undeveloped portions of the collection system right-of-way would be graded, seeded, and maintained for ease of future access.

The process water flow equalization basin would be located in the confluence of the two existing drainage features located to the west and north of the SREL graveled access road (Figure 2-2). The basin would impound an area of approximately 0.8-2.0 hectares (2-5 acres) in size behind the earthen berm supporting the adjacent roadway. Minimal site clearing and grading would be required during the construction of this impounded area. The site clearing for this facility would encompass some timber harvesting, grubbing, and debris removal. The capacity of the basin, controlled by a standpipe structure discharging into the existing culvert, would be designed for approximately 3.8 million liters (1.0 million gallons). Piping similar to that used for the collection system would then be installed to enable a gravity-feed of this impounded water into the wetland cell facility. Excess runoff produced by storm events would be discharged down the standpipe and through the culvert into Tim's Branch. An ongoing SRS project to identify and reduce copper in stormwater runoff within SRTC should achieve compliance levels of this parameter in the downgradient waters of the State during such storm events. Should these efforts not result in the necessary source reduction of copper, additional stormwater detention capacity would be constructed adjacent to the wetland cells facility. In the event that this decision to construct additional stormwater capacity is reached, the process water flow equalization basin would not be constructed, and a stormwater detention basin (i.e., design basis to contain a 25 -year/24-hour storm event) would be incorporated into the proposed project scope at the additional cost of approximately $\$ 500,000$ above the current project estimate. The project's pipeline collection system would also be rerouted to discharge directly into this stormwater detention basin.

The subsurface flow wetland cell facility would be built in an undeveloped area located to the southeast of the SREL graveled access road (Figure 2-2). The footprint of the proposed facility would encompass approximately 6.1-6.5 hectares (15-16 acres) of 
currently undeveloped lands. The constructed wetland cell facility would be permitted as an industrial wastewater treatment facility by SCDHEC. This facility would consist of a series of interconnected artificial wetland cells to treat the outfall effluent. The gavity-fed pipeline from the process water flow equalization basin would discharge directly into a small receiving basin at the edge of the facility. From the receiving basin, the effluent would be distributed into and filtered through the wetlands to an outlet collection system. The treated effluent would then be piped to the new outfall discharge structure on Tim's Branch. Should additional stormwater capacity be required, it would both physically and functionally replace the small receiving basin within the process flow through this facility.

Construction of the wetland cell facility would include site clearing, grading, excavation, backfilling, access road construction, installation of monitoring wells, and site seeding/landscaping. General site clearing would encompass timber harvesting, grubbing, and logging/clearing debris removal or burning. An access road leading from the SREL graveled access road and ending in a turn-around or parking area adjacent to the wetlands/basin complex would also be constructed.

The wetland cell facility would be excavated, surrounded by earthen containment berms, and lined to prevent any seepage into the surrounding environment. The liner would consist of a geomembrane liner and/or a soil liner with a hydraulic conductivity of $1 \times 10^{-6}$ $\mathrm{cm} / \mathrm{sec}\left(3.9 \times 10^{-7} \mathrm{in} / \mathrm{sec}\right)$ or less. The geomembrane material would be selected to be able to withstand loads imposed during construction activities. A series of monitoring wells would be installed around the facility to detect any leakage from the treatment facility. A layer of filter media capable of reducing the effluent constituents would be placed on the bottoms of the wetland cells. The surface area required, depth of media, and flow characteristics through the media would be determined at a later date. Both the filter media and liner would be designed and selected for long-term ease of performance, operation, and maintenance. Aquatic floral species may be planted in the wetland cells as an additional measure to control erosion and enhance metal-removal efficiencies. Species selection of these plants would be recommended by SREL and the U.S. Forest Service.

The wetland cell facility would be designed to treat a flow of approximately 2.7 million liters per day ( 0.7 million gpd), excluding storm water surges. This facility would be designed for a semi-constant flow rate without the system either going dry or flooding. The design of the facility would also allow for maintenance activities. Individual cells could be shut down for maintenance while the remaining cells continued to operate. The system would be operated continuously and would meet the effluent criteria during maintenance activities. The filter media or liner containing the captured metals in each cell would be removed and disposed of upon exhaustion of the filtering capacity. During operations, visual inspections of the treatment facility would be conducted on a daily basis (i.e., on work days only) during daylight hours due to the lack of electricity at the site. 
The last portion of the proposed action would be the construction of the discharge pipeline and outfall structure. This activity would entail placement of an outflow pipe from the wetland cell facility downslope to the area adjacent to Tim's Branch, construction of an outfall structure on the margin of the stream channel, and placement of riprap within the streambed. The location of the proposed new outfall would be on the south side of the Tim's Branch stream corridor. The pipeline right-of-way would be cleared. A temporary access road for construction vehicles would also be built within that right-of-way. The pipeline would either be routed above grade on support pillars or below grade until it reaches the outfall structure. The outfall structure would consist of a concrete headwall supporting the discharge pipe above the receiving stream. Large riprap would be placed within the streambed of Tim's Branch at the outfall location to prevent erosion and scouring by the discharged effluent. A pedestrian path would be built between the turn-around/parking area at the wetland cell facility and the outfall structure to provide readily available and safe access for sampling activities. If needed, stairs or steps leading down to a platform would be installed at the new NPDES compliance sampling point.

Best management practices would be employed during construction and maintenance activities associated with this proposed action. Specific erosion control and storm water management practices (e.g., placement of silt fences) would be employed to ensure there is no deposition of erosional material or sediment into the downslope wetland areas during construction. A number of mitigation activities would be implemented to minimize potential impacts to the floodplain and wetlands. Operation of construction equipment in the wetland and floodplain areas would be minimized. Silt fences and other erosion control structures as needed would be installed to ensure there is no deposition in the downslope wetland areas. Minimal wetland acreage (i.e., less than 0.3 acres) would be impacted as a result of fill associated with the aforementioned outfall structure and placement of riprap material in the streambed. An erosion control plan would be developed so that the proposed action complies with applicable State and local floodplain protection standards and further to ensure that no additional impacts to wetlands will occur due to erosion and sedimentation.

\subsection{Alternatives to the Proposed Action}

In accordance with NEPA regulations, DOE examined the following alternatives to the proposed action:

- No action, continue to use the existing outfalls

- Install a pipeline to discharge directly into Upper Three Runs

- Build a full-scale ion exchange facility

- Relocate the A-01 Outfall and use an existing wetlands area 


\subsubsection{No Action, Continue to Use the Existing Outfalls}

One alternative to the proposed action is to take no action. This would consist of SRS continuing to use the existing outfalls that contribute to the A-01 effluent. The contaminant levels in this effluent would remain unchanged, and would therefore continue to exceed the new outfall limits for copper and chronic toxicity. Selection of this alternative would result in the site being in violation of the new limits when these go into effect next year.

\subsubsection{Install a Pipeline to Discharge Directly into Upper Three Runs}

This alternative would involve the installation of a pipeline collection system of the various outfalls, which would then discharge directly into Upper Three Runs. This alternative would entail the placement of approximately $5.3 \mathrm{~km}(3.3 \mathrm{mi})$ of underground pipeline sited over uneven terrain and through variable habitats. Almost the entire length of the proposed pipeline route would be through undeveloped portions of SRS. Although this alternative would result in an outfall which would be in compliance, it would also be very expensive and result in more environmental impacts as compared to implementing the proposed action.

\subsubsection{Build a Full-Scale Ion Exchange Facility}

A third alternative would be to construct a full-scale ion exchange facility to collect and treat the A-01 effluent streams. The scope of this alternative would be to place multiple skid-mounted ion exchange (SMIX) units designed for the flow rates at the A-01 outfall. Each SMIX unit is a highly integrated and fully automatic system which features a buffer tank, $\mathrm{pH}$ control, pumping system, media filter, ion exchange columns, resin, modular valve systems, and an overall control system. The ion exchange system could operate continuously. Although technically feasible, this alternative would be more complex and costly compared to the proposed action. The total estimated cost (i.e., $\$ 3.3$ million) does not include the required retention basin designed for a 25 -year storm event.

\subsubsection{Relocate the A-01 Outfall and Use an Existing Wetland Area}

The last alternative would consist of relocating the A-01 outfall further downstream in Tim's Branch in an area below an existing emergent marsh wetland situated within the stream channel (Payne 1996). This wetland consists of a portion of the stream channel that has been impounded by a culverted road crossing. This portion of Tim's Branch has already realized the benefit of some treatment in the form of streambed soils naturally binding metals out of the stream effluent because of both the downstream location (relative to the existing A-01 outfall) and the reduced-flow impounded conditions. The result is a reduced level of copper in the effluent being discharged through the culvert pipe draining the impounded area. This alternative, therefore, would take advantage of a naturally occurring process to achieve compliance with the new limits. The cost of implementing this alternative would be small and the implementation time would be 
short. However, subsequent discussion of this alternative with SCDHEC identified this impounded area as waters of the State. SCDHEC further stated that treatment of the A-01 outfall effluent would have to take place before reaching any waters of the State. Except for relocating the NPDES sampling location further downstream, implementation of this alternative would be effectively the same as that of the no-action alternative.

\subsection{AFFECTED ENVIRONMENT}

SRS occupies an area of approximately 800 square kilometers (300 square miles) in southwestern South Carolina (Figure 1-1). The site borders the Savannah River for about 27 kilometers (17 miles) near Augusta, Georgia, and Aiken and Barnwell, South Carolina. SRS contains five non-operational nuclear production reactor areas, two chemical separations facilities, waste treatment, storage and disposal facilities, and various supporting facilities. The Final EIS for the Shutdown of the River Water System at SRS (DOE 1997) and the most recent socio-economic survey of the six-county SRS area of influence (HNUS 1997) contain additional information on SRS facilities and the areas surrounding the site.

\subsection{Land Use}

Most of the proposed project area is currently occupied by either planted pine forest or previously developed area (e.g., graveled parking lots) (Figure 2-2). A small portion associated with the location of the proposed outfall structure is occupied by bottomland hardwood forest. Since 1980, with exception of the last habitat type mentioned, the property encompassed by the scope of the proposed action has been used as either developed land or for timber production. Some limited ecological research has been conducted in this area in the past; however, there are no environmental or ecological research activities either ongoing or planned for the future on these lands.

\subsection{Geology and Seismology}

SRS is located in the Aiken Plateau physiographic region of the upper Atlantic Coastal Plain approximately 40 kilometers ( 25 miles) southeast of the Fall Line which separates the Piedmont Plateau from the Atlantic Coastal Plain. The topographic surface of the coastal plain slopes gently seaward and is underlain by a wedge of seaward-dipping unconsolidated and semiconsolidated sediments from the Fall Line to the coast of South Carolina. The Atlantic Coastal Plain tectonic province in which SRS is located is characterized by generally low seismic activity that is expected to remain subdued (Haselow et al. 1989).

The areas encompassed by the proposed action have been somewhat modified historically from the surrounding environs. Approximately one-half of the area to be occupied by the collection pipeline is comprised of Udorthents, well-drained soils formed in heterogeneous materials placed during construction of the existing facilities. The 
remaining one-half of the route is divided evenly between Vaucluse-Ailey complex soils and Dothan sands. The Vaucluse and Ailey series soils consist of well-drained, slowly permeable soils that formed in thick beds of unconsolidated sand and clay in the Sand Hills. These soils are characteristic of long, narrow ridgetops and short, complex side slopes. The Dothan sands are well drained, moderately permeable soils that formed in thick beds of unconsolidated sandy and loamy marine sediments. These soils are typically found on broad ridgetops and fairly smooth side slopes of the Coastal Plain and are intermingled with other soils of the Sand Hills. The proposed process water flow equalization basin location is completely composed of Vaucluse-Ailey complex soils. The proposed location of the wetland cell facility is occupied by Fuquay sands. These are well-drained, slowly permeable soils that formed in loamy marine sediment on the upper Coastal Plain and the Sand Hills. These soils are on broad ridges and side slopes. The area encompassing the outlet/outfall system is occupied by Fuquay sands and Vaucluse-Ailey complex soils. The overall area is generally flat, with a slight down-sloping aspect in an east-southeasterly direction (Rogers 1990).

No geologic faults are located within the proposed project area. The most active seismic zones in the southeastern United States are all located over 160 kilometers (100 miles) away from the site. A recent EIS (DOE 1997) contains information on SRS fault location and earthquake occurrences.

\subsection{Hydrology}

The Savannah River forms the western boundary of SRS and receives drainage from five major tributaries on the site: Upper Three Runs, Fourmile Branch, Pen Branch, Steel Creek, and Lower Three Runs. These tributaries receive varying types of wastewater discharges from plant processes and sanitary treatment systems, all of which are permitted through the NPDES regulatory compliance process. On SRS, various plant processes also require the pumping of Savannah River water and/or onsite groundwater. A recent EIS (DOE 1997) contains information on surface water and groundwater resources on SRS and in the surrounding region.

The proposed project is primarily located on an upland area which drains to the east-southeast (USGS 1988). The nearest 100-year floodplain and jurisdictional waters/wetlands are those associated with Tim's Branch drainage corridor, a lateral tributary of Upper Three Runs (NUS Corporation 1984, Lanier 1996). The uppermost portions of both the baseline floodplain and wetlands within Tim's Branch originate at the culvert pipe under the SREL graveled access road. The area above that road is not considered to be either 100-year floodplain or waters of the State/wetlands. In addition, a Carolina bay is situated approximately 52 meters (170 feet) to the west-southwest and upslope of the proposed detention basin/wetlands complex boundary.

The portion of the Tim's Branch stream corridor associated with the proposed outfall structure is composed of both 100-year floodplain and jurisdictional waters/wetlands. At the site of the proposed outfall, the 100-year floodplain is approximately 20-50 meters 
(65.6-164 feet) across the drainage corridor, while the wetlands habitat at that point is approximately $2-4$ meters (6.7-13.1 feet) wide. The floodplain is periodically flooded, but not for periods sufficient to make it jurisdictional. This headwaters drainage is characterized by a stream channel which is deeply cut into the bottomland and the streambed is situated approximately 1-3 meters (3.3-9.8 feet) below the grade of the surrounding forest floor. The hydrology supporting this drainage system is provided through effluent from the local outfalls and storm water runoff from the surrounding higher elevation lands. The soils within the stream channel appear to be largely erosional sediment in composition.

The depth to uppermost groundwater varies from 4.6-10.7 meters (15-35 feet) below grade in the area of the collection pipeline, proces water flow equalization basin, and wetland cell facility. The direction of flow of the uppermost groundwater is upward and to the east-southeast.

\subsection{Ecological and Cultural Resources}

Since 1951, when the U.S. Government acquired SRS, natural resource management practices and natural succession outside of the construction and operation areas at SRS have resulted in increased ecological complexity and diversity of the site. Forested areas support a diversity of wildlife habitats that are restricted from public use. Forest management practices include controlled burning, harvesting of mature trees, and reforesting. Wildlife management includes control of white-tailed deer (Odocoileus virginianus) and wild swine (Sus scrofa) populations through supervised hunts. SRS, which was designated as the first National Environmental Research Park in 1972, is one of the most extensively studied environments in this country. Halverson et al. (1997) contains additional information on the biotic characteristics of SRS.

Six species on SRS are afforded protection by the Federal Government under the Endangered Species Act of 1973. These are the bald eagle (Haliaeetus leucocephalus), wood stork (Mycteria americana), red-cockaded woodpecker (Picoides borealis), American alligator (Alligator mississippiensis), shortnose sturgeon (Acipenser brevirostrum), and smooth purple coneflower (Echinacea laevigata). None of these species have been documented or observed as either occurring on or using the lands either within or adjacent to the proposed project location (Wike et al. 1994, Imm and Jarvis 1998).

The location for the proposed process water flow equalization basin is currently occupied by a mixed pine and hardwood forest. A mature forest canopy, dominating this topographic drainage feature, consists of a mixture of loblolly pine (Pinus taeda), sycamore (Platanus occidentalis), sweetgum (Liquidambar styraciflua), water oak (Quercus nigra), hackberry (Celtis laevigata), and hickory (Carya spp.). The mid-story component primarily includes saplings of the overstory species, as well as scattered red maple (Acer rubrum) and flowering dogwood (Cornus florida). Understory species 
include seedlings of the aforementioned species, and a variety of herbaceous species dominated by blackberry (Rubus spp.).

The proposed project area associated with the wetland cell facility is located in a planted and managed longleaf pine ( $P$. palustris) stand. This pine plantation has been managed by the U. S. Forest Service over the past four decades for timber production purposes only. This area has a closed overstory canopy of pure longleaf pine. No mid-story component is present in this area due to the management regime. Very limited and sparse understory and herbaceous components, with scattered seedlings of longleaf and loblolly (P. taeda) pine. Also present but scarce are seedlings of winged elm (Ulmus alata), sassafras (Sassafras albidum), and American holly (llex opaca). Scattered vines of jasmine (Gelsemium sempervirens) and greenbrier (Smilax spp.) are also present. A thick pine duff or litter layer is present across this entire portion of project area.

The habitat type in the area of the proposed outfall to Tim's Branch is a mixed hardwood, bottomland forest occupying a mesic headwater area. Predominant overstory species include loblolly pine, sweetgum, water oak, hackberry, and hickory. Further down from the location of the proposed outfall structure, sycamore becomes a component of the overstory. The mid-story component in this area includes saplings of the overstory species in addition to American holly and wax myrtle (Myrica cerifera). The understory include seedlings of these species, with large areas of jasmine vines and lesser areas of greenbrier. The litter area of the 100-year floodplain is predominantly intact and only the stream channel shows erosional characteristics.

Several wildlife species have been observed in and around the general area of the proposed project location. The wildlife species composition is comparable to similar habitat types elsewhere on SRS. Comprehensive listings of wildlife species can be found in Halverson et al. (1997) and Mayer and Wike (1997).

The management and utilization of forests, soils, watersheds, and wildlife at SRS are described in the SRS Natural Resources Management Plan (DOE 1991) and defined under the terms of a Memorandum of Agreement between DOE Savannah River Operations Office (SR), U.S. Forest Service Savannah River Natural Resource Management and Research Institute (SRI), the Natural Resources Conservation Service, and Westinghouse Savannah River Company (WSRC). DOE-SR uses this Memorandum of Agreement to define the roles and responsibilities of the various agencies and organizations in the management of natural resources on SRS.

The entire proposed project location is situated within the medium or Type II archaeological sensitivity zone for SRS (SRARP 1989). The areas specifically proposed for development have been reviewed by the University of South Carolina's Savannah River Archaeological Research Program (SRARP). No complex archaeological or potential National Register of Historic Places eligible sites were identified within the proposed project location. Cultural resources at SRS are managed under the terms of a Programmatic Memorandum of Agreement among DOE-SR, the South Carolina State 
Historic Preservation Officer, and the Advisory Council on Historic Preservation. DOE-SR uses this Programmatic Memorandum of Agreement to identify cultural resources, assess these in terms of National Register eligibility, and develop mitigation plans for affected resources in consultation with the South Carolina State Historic Preservation Officer. DOE-SR would comply with the stipulations of the Programmatic Memorandum of Agreement for all activities related to the proposed A-01 outfall constructed wetlands project.

\subsection{Radiation Environment}

A person residing in the Central Savannah River Area (within 80 kilometers or 50 miles of SRS) receives an average annual radiation dose of about $360 \mathrm{mrem}$; SRS contributes less than 0.1 percent of that total. Natural radiation sources contribute about $300 \mathrm{mrem}$, medical exposures contribute about $53 \mathrm{mrem}$, and consumer products contribute about 10 mrem. The most recent SRS annual environmental report and data summary (Arnett and Mamatey 1997a, 1997b) contain more information on the radiation environment.

Two sources of radionuclide contamination have taken place in the lands encompassing the proposed action project site. The first occurred between 1969 and 1973, when a collective total of approximately 0.39 curies of the isotope Curium ${ }^{244}$ was released from Building 773-A into Tim's Branch (DuPont 1988). The other radiological contamination found in the proposed project area is in the groundwater, having originated from the SRL basins. These four basins, which stopped receiving waste in October 1982, contain elevated levels of heavy metals, fluoride, sodium, phosphate, tritium, and other radionuclides. Previous analyses have indicated that the SRL basin groundwater contamination would have little to no impact on either the environment or to human health (DOE 1987). This multi-basin waste site is currently being cleaned-up prior to closure.

\subsection{ENVIRONMENTAL CONSEQUENCES OF THE PROPOSED ACTION AND ALTERNATIVES}

\subsection{Project Construction}

A number of activities related to the proposed action would take place within previously developed areas. Following completion of the construction activities, these areas would be restored to support their previous uses (e.g., roads and parking lots). The portions of the project area which are currently used for timber production would be permanently altered by the proposed action. As such, these lands would be eliminated for any future use as pine plantation. The proposed action would eliminate approximately $6.1-6.5$ hectares (15-16 acres) of planted pine habitat. This represents less than 0.013 percent of this type of habitat currently found on SRS. The same amount of acreage would be eliminated from future use for any environmental or ecological research activities. Some small areas, both around the developed and undeveloped project locations, may also be 
used as temporary lay-down yards or for equipment storage. Therefore, land use impacts due to construction activities associated with the A-01 outfall constructed wetlands project would be small.

The direct and indirect socioeconomic impacts of the peak project construction work force of 40-50 would be negligible when compared to the present total SRS employment of approximately 15,000 people (HNUS 1997). This work force would be drawn from both local and non-local sources as determined by skilled worker availability. No measurable impact on the local economy would be expected from the proposed action.

The proposed action would not require the use of any groundwater resources. The only surface water resources which would be utilized in association with the proposed action would be that portion of the outfall effluent created by storm water runoff. This along with the process water discharged from the various outfalls would be tied into the collection pipeline discharging into the process water flow equalization basin and wetland cell facility.

The clearing of the sites for the process water flow equalization basin and wetland cell facility would limit the use of these lands by wildlife species. Some of the small, less mobile species of mammals, reptiles and amphibians would possibly be either physically harmed or killed by the logging and earth-moving equipment. However, most species of mammals and birds which inhabited or used the project areas would be largely displaced by the land clearing, but probably not either injured or killed. Those animals displaced by construction into adjacent or marginal habitats may either die or experience reduced reproduction. The net result would be a lower quality habitat being available and therefore fewer individual animals being present.

The selling of some merchantable timber would be involved in the clear cutting of the undeveloped portions of the proposed project areas. Approximately 12,355 board feet of timber per hectare (5000 board feet of timber per acre) or a combined total of $85,000-100,000$ board feet is expected to be ultimately harvested from the entire project. Clearcutting of the proposed project site would represent the loss of less than 0.05 percent of the site's mixed pine and hardwood forest, and less than 0.013 percent of planted pine forest on SRS. This would be expected to result in only a negligible impact.

Construction-related air quality effects would primarily be due to temporary equipment use. Diesel operated equipment (i.e., trucks, backhoes, graders) would be used for excavation, grading and other routine construction activities. The operation of this class of equipment does not require an air quality permit from SCDHEC. In addition, adequate measures would be implemented to minimize and control fugitive dust during construction activities. site safety and health personnel would take air samples during construction activities to enable air quality impacts to be held to a minimum.

The proposed construction would generate minor amounts of some construction-related debris or rubble. The specific project sites (e.g., collection pipeline route, process water 
flow equalization basin, and wetland cell facility locations) are not known to contain any hazardous, toxic, and/or radioactive material. Nevertheless, the potential exists (especially with the close proximity of the SRL basins) that construction-related activities such as excavation could result in the discovery of previously unknown hazardous, toxic, and/or radioactive material. If such material were discovered, DOE would remove and dispose of such material in accordance with all applicable laws and regulations. The various uncontaminated or contaminated waste streams would then be transported to and disposed of at either the municipal solid waste disposal site in use at that time (e.g., Hickory Hill Landfill or Three Rivers Solid Waste Authority Regional Landfill), the SRS erosion control pit, or the SRS Solid Waste Management Area (i.e., E Area), as appropriate. The management, transportation, and disposal of such wastes has already been addressed in DOE (1994), DOE (1995a), and DOE (1995b). In addition, the soils removed during excavation activities for the wetland cell facility potentially may be used as backfill for the closure of some of the SRL basins. No new waste streams or types of waste would be generated during the construction phase of the proposed action. These project activities would be expected to have only a minimal impact on site waste management operations.

The project construction activities would result in a less than 1 percent increase in the site traffic volumes on SRS Road A-1. This would primarily encompass the transportation of equipment, construction materials, and the waste generated during the construction phase of the proposed action. Since the current traffic volume on this site road is below the design capacity, transportation impacts associated with a minor increase in construction traffic would be negligible. The excavation, placement of the pipeline, backfilling, and repaving of the collection pipeline portion designed to go under SRS Road A-1 would result in temporary traffic delays or detours for site traffic.

A small area (i.e., less than 0.3 acres) of 100-year floodplain and jurisdictional wetlands would be impacted by the construction of the outfall structure on Tim's Branch. The consequences associated with this portion of the proposed action are discussed in Appendix A of this EA.

No threatened or endangered species have been identified in the vicinity of the proposed project site from either previous or recent surveys (Wike et al. 1994, Halverson et al. 1997, Imm and LeMaster 1998). The habitats in the vicinity of the project site are not suitable for any of the federally-protected species that have been identified at SRS except for the red-cockaded woodpecker. The distance to the nearest active colony for the red-cockaded woodpecker from the proposed facility is $12.1 \mathrm{~km}(7.5 \mathrm{mi})$ in an east-northeasterly direction. The proposed site is beyond the typical foraging distance for this species as reported on SRS. Therefore, no impacts on any threatened or endangered species would be expected as a result of the construction portion of the proposed action. A copy of the biological evaluation (i.e., Imm and Jarvis 1998) of the proposed project site was forwarded to the U. S. Fish and Wildlife Service (USFWS) in Charleston, South Carolina. Upon completion of their review, that Federal agency concurred on a 
determination of no expected impact on protected species as a result of the proposed action (EuDaly 1998).

As part of the routine SRS Site Use Permit system, each prospective project site is also reviewed for potential archaeological impacts. There are no known archaeological or cultural resources found within the proposed project area. Since the project location is encompassed within the medium or Type II archaeological sensitivity zone for SRS, little to no impacts to site cultural resources would be expected as a result of the proposed action. Care would be taken during excavation activities to detect the presence of any such artifacts or remains. These construction activities would be temporarily halted until such time as the significance of these resources could be evaluated and removed if necessary.

The Occupational Safety and Health Act (OSHA) requires that employers comply with the safety and health standards set by the act (29 CFR Part 1910) to provide each employee with a worksite that is free from recognized hazards that are likely to cause death or serious injury. Temporary barricades and signs would be installed during construction to prevent entry of unauthorized personnel at the project site. Aside from unexpected construction accidents, the only potential impacts to human health and worker safety associated with the construction portion of the proposed action would be encountering contaminated soils during excavation activities. Site Health Physics professionals with the necessary monitoring equipment would be available during all of the excavation activities adjacent to SRTC and around the SRL basins. Appropriate protective measures would be implemented if the situation presenting a potential for either a radiological exposure or hazardous material contact should arise.

\subsection{Normal Operation}

The operation of the A-01 outfall constructed wetlands project would take place entirely within the area already impacted by the project's construction activities. Therefore, land use impacts associated with operational portion of the proposed action would be negligible.

The proposed facility would be operated by four to five people. These personnel are currently those site employees who already manage a nearby wastewater treatment facility. No new employees would be hired in support of the proposed action. Socioeconomic impacts of the proposed action would be inconsequential.

Aside from the collection of storm water runoff, no surface water would be used during operation of the constructed wetlands project. In addition, there would be no groundwater usage associated with this phase of the proposed action.

The volume of treated effluent being discharged into Tim's Branch would be equivalent to the process and stormwater effluent being discharged into that drainage by current operations. In addition, the project would also provide a more constant effluent volume 
to Tim's Branch. As such, the implementation of the proposed action would have a negligible impact to the receiving stream from a volume input perspective. Except during storm events, the potential does exist for low-flow conditions to be created above the new outfall structure within Tim's Branch because of the rerouting the current outfall discharges. However, since this portion of Tim's Branch is largely devoid of any invertebrate or vertebrate fauna, the impacts of low flow conditions would be minimal. Because of the wastewater treatment function of the proposed action, the effluent being discharged would have lower levels of contaminants than are currently realized. This should result in an improvement to the water quality within this drainage corridor.

Given the undeveloped nature of the immediate surrounding lands, the use of the wetland cell facility by semi-aquatic wildlife species does have the potential to occur. Based on earlier observations at the SRL basins and other constructed aquatic habitats on site, one could expect to find waterfowl [e.g. pied-billed grebe (Podilymbus podiceps) and wood duck (Aix sponsa)], turtles [e.g., yellow-bellied turtle (Trachemys scripta)], salamanders [e.g., mole salamander (Ambystoma talpoideum)], and frogs/toads [e.g., southern toad (Bufo terrestris), bullfrog (Rana catesbianea), and southern leopard frog (R. utricularia)] (Mayer and Wike 1997) in this type of habitat. For those species which might remain in residence in this aquatic system for extended periods of time, the potential could exist for an impact resulting from the elevated levels of certain contaminants (e.g., copper) accumulated within this wastewater treatment facility.

Impacts to waterfowl from use of the wetland cell facility would be minimized by selecting those species of aquatic plants which will remove the contaminants but which are not preferred forage species for either the pied-billed grebe or the wood duck. Further, since most metals in this type of system are retained in the soils and fine roots of any plants present (Sinicrope et al. 1992), these contaminants would be largely unavailable to waterfowl species foraging on only stems, leaves, large roots, and tubers. Both of these species also forage on aquatic invertebrates, which would be expected to colonize and be present in the constructed wetland cell facility. However, since the presence of humans is a deterrent to both of these wild birds, the daily maintenance activities by the facility staff should discourage the occupation by either of these species for any extended period of time.

With respect to the reptile and amphibian species, the placement of metal sheeting around the base of a perimeter fence could be used to exclude a number of these species. The presence of these species should also be monitored over the operational life of the facility for any potential impacts (e.g., physical malformations, large-scale die-offs, etc.).

The only solid waste streams which would be generated during operations of the proposed facility would be in the form of the individual wetland cell bed media and liner, when these need to be replaced. All of this solid waste would be transported to and disposed of at an appropriate waste disposal facility. 
Increases in traffic volume associated with the operational portion of the proposed action would be negligible. Nearly all of the transportation associated with operational activities of the proposed wetland cell facility would take place on secondary site roads (e.g., SREL graveled access road) which currently experience only very low levels of traffic volume on a daily basis.

The primary potential impact to human health and worker safety would be in the form of health effects due to the chronic exposure to contaminants trapped within this wastewater treatment facility. This potential exposure would occur during the removal of exhausted bed media and liners from the wetland cells. To minimize the potential for an exposure, protective clothing (e.g., rubber gloves and boots, and waterproof coveralls) would be used during any facilities' activities which would require contact or handling of the bed media, liner, or other similar components of the wetland cell facility.

The facilities involved in the proposed action are located entirely within the general site access portion of SRS. All existing security systems and programs for the general site would be extended to the facilities involved in the proposed action. No additional safeguard and security measures would be required for implementing the proposed action.

\subsection{Accident Analysis}

The maximum reasonably foreseeable accident associated with the proposed action would be a 100-year storm event breaching the containment berms of the wetland cell facility. The consequence of this scenario would be the uncontrolled release of some of the effluent from the wetland cells into the surrounding upland landscape. The potential would also exist for some of the bed media to be forced out of the cells during the course of the breaching incident. With such an accident scenario, the primary impact would result from the contaminated bed media being flushed onto the adjacent lands. This would require a rapid and thorough clean-up following such an accident to remediate any potential impacts that the contained contaminants might have on the surrounding environs.

\subsection{Environmental Consequences of the Alternatives}

The no-action alternative would create none of the construction or operational impacts associated with the proposed action. However, implementation of the no-action alternative would ultimately result in an NPDES violation when the new outfall limits become effective in 1999.

The alternative involving the installation of a pipeline discharging directly to Upper Three Runs would result in land use changes along the entire $5.3 \mathrm{~km}(3.3 \mathrm{mi})$ route of this pipeline. Assuming a cleared right-of-way of approximately $10 \mathrm{~m}(33 \mathrm{ft})$ in width (i.e., allowing for construction and maintenance access), the total land area impacted by this alternative would be approximately 5.3 hectares (13.2 acres). The upper reaches of Tim's Branch in the vicinity of SRS Road A-1 and the SREL graveled access road would be 
converted to a lower flow regime, similar to that of the proposed action. Without the other outfalls contributing to this drainage, any flow additions to the A-1A effluent or the contaminated groundwater outcropping from the SRL basins in Tim's Branch would only be realized during stormwater events.

The alternative to build a full-scale ion exchange facility would result in approximately the same amount of land use impacts as the proposed action. This alternative would require the construction of a collection pipeline similar to that of the proposed action, and the installation of multiple SMIX units with a stormwater retention basin would occupy a footprint similar to that of the wetlands/detention basin complex. However, this operational complex would probably be located closer to the Tim's Branch drainage corridor. The disposal of the exhausted resin from the ion exchange columns would be more frequent than that needed for the bed media/liner waste stream of the proposed action. However, the volume of the exhausted resin waste stream would be much lower than that of the bed media/liners over the short-term time frame. Because the specific resin for use in this alternative has not been selected, it is not possible to estimate the overall waste stream volumes in comparing this alternative with those of the proposed action over the operational lives of these alternatives.

The final alternative of relocating the outfall and using an existing impounded area downstream of the proposed project location would have most of the same impacts as the no-action alternative. The one exception would be that the NPDES compliance sampling point would be relocated to the downstream side of this impounded area. The impacts associated with allowing untreated effluent to continue to drain thorough the upper reaches on Tim's Branch would still be realized.

\subsection{Cumulative Impacts}

The principal cumulative impacts from the proposed action would be those effects associated with the loss of less than 1 percent of site forested habitat and the current site use of less than 1 percent of lands encompassed by SRS. Specifically, the site lands available for timber management and environmental/ecological research would reduced by 0.013 and 0.009 percent, respectively. There would be no measurable impact on the local economy as a result of the proposed action. Some individual mortality of wildlife species and a less than 0.005 percent loss of available wildlife habitat on SRS would result with the construction of the proposed wastewater treatment facility. The proposed facility would have no adverse impacts on threatened and endangered species or cultural resources. The impacts to 100-year floodplain and jurisdictional wetlands would be minor. Cumulative ambient air quality impacts would be negligible. Assuming that both protective clothing and adequate safety measures are utilized, the proposed action should not pose any potential problems for either human health or worker safety. There would be no measurable impact to either public health and safety as a consequence of the proposed action. Negligible traffic and transportation impacts would result from implementation of the proposed action. No adverse impacts to either surface or groundwater quality would be expected from the operation of the proposed action. The 
surface water quality in Tim's Branch would improve following operational start-up of the proposed facility.

\subsection{REGULATORY AND PERMITTING PROVISIONS CONSIDERED}

DOE policy is to carry out its operations in compliance with all applicable Federal, State and local laws and regulations, as well as all DOE Orders. This section provides a discussion of the major regulatory permit programs that might be applicable to the proposed action.

\subsection{National Environmental Policy Act of 1969, as amended (42 USC 4321 et seq.)}

This EA has been prepared in accordance with NEPA of 1969, as amended, and with the requirements of the Council of Environmental Quality Regulations for Implementing NEPA (40 CFR Parts 1500-1508), DOE Regulations (10 CFR Part 1021), and DOE Order 451.1A. NEPA, as amended, requires "all agencies of the Federal Government" to prepare a detailed statement on the environmental effects of proposed "major Federal actions significantly affecting the quality of the human environment." This EA has been written to comply with NEPA and assess the environmental effects of the A-01 outfall constructed wetlands project at SRS.

\subsection{Solid Waste Regulations}

Small amounts of solid waste materials (e.g., construction rubble and debris) would be deposited in the municipal solid waste facility being used by SRS at that time. In addition, any low-level contaminated operational waste would be disposed of onsite as necessary. These activities would be part of ongoing already permitted SRS waste management activities.

\subsection{Air Emission Regulations}

Operation of the class of construction equipment to be used in implementing the proposed action does not currently fall within the SCDHEC requirements for air permitting activities. The use of any diesel generators during construction activities would be prescreened for permitting requirements under Title $\mathrm{V}$.

\subsection{Liquid Discharge Regulations}

The discharge of both stormwater and process water from the A-01 outfall is an already permitted NPDES activity. These permits would be modified as necessary to include the proposed wastewater treatment facility. 


\subsection{AGENCIES AND PERSONS CONSULTED}

Staff professionals from the U.S. Forest Service SRI and the U.S. Fish and Wildlife Service were consulted during the preparation of this EA. 


\subsection{REFERENCES}

Arnett, M. W., and A. R. Mamatey (editors), 1997a. Savannah River Site Environmental Report for 1996, WSRC-TR-97-0171, Westinghouse Savannah River Company, Savannah River Site, Aiken, South Carolina.

Arnett, M. W., and A. R. Mamatey (editors), 1997b. Savannah River Site Environmental Data for 1996, WSRC-TR-97-0077, Westinghouse Savannah River Company, Savannah River Site, Aiken, South Carolina.

Broaden, D. A., 1996. Alternative Study of Potential Systems for Reducing Copper and Lead Concentrations in Process Water Effluents from the New A-01 Outfall (U), WSRC-RP-96-491, Westinghouse Savannah River Company, Savannah River Site, Aiken, South Carolina.

DOE (U. S. Department of Energy), 1987. Final Environmental Impact Statement: Waste Management Activities for Groundwater Protection, Savannah River Plant, South Carolina, DOE/EIS-0120, Savannah River Operations Office, Aiken, South Carolina.

DOE (U. S. Department of Energy), 1991. Natural Resources Management Plan: Strategic Guidance for the Savannah River Site's Natural Resources Programs, Savannah River Operations Office, Aiken, South Carolina.

DOE (U. S. Department of Energy), 1994. Environmental Assessment for the Transportation and Disposal of Savannah River Site Generated Municipal Solid Waste at an Off-Site Disposal Facility, DOE/EA-0989, Savannah River Operations Office, Aiken, South Carolina.

DOE (U. S. Department of Energy), 1995a. Savannah River Site Waste Management Final Environmental Impact Statement, DOE/EIS-0217, Savannah River Operations Office, Aiken, South Carolina.

DOE (U. S. Department of Energy), 1995b. Environmental Assessment for the Construction and Operation of the Three Rivers Solid Waste Authority Regional Waste Management Center at the Savannah River Site, DOE/EA-1079, Savannah River Operations Office, Aiken, South Carolina.

DOE (U. S. Department of Energy), 1997. Environmental Impact Statement for Shutdown of the River Water System at the Savannah River Site, DOE/EIS-0268, Savannah River Operations Office, Aiken, South Carolina.

Dukes, M. D., 1997. Westinghouse Savannah River Company, Savannah River Site, Aiken, South Carolina, letter to B. L. Foster, South Carolina Department of Health 
and Environmental Control, Columbia, South Carolina, Savannah River Site National Pollutant Discharge Elimination System (NPDES) 2C Application for Outfall A-01 for NPDES Permit SC0000175, December 15.

DuPont (E. I. du Pont de Nemours and Company, Inc.), 1988. Releases of Radioactivity at the Savannah River Plant, DPSPU-86-25-1, Rev. 6, E. I. du Pont de Nemours and Company, Inc., Health Protection Department, Savannah River Plant, Aiken, South Carolina.

Eudaly, E. M., 1998. U. S. Department of the Interior, Fish and Wildlife Service, Charleston, South Carolina, letter to S. A. Danker, Department of Energy, Savannah River Operations Office, Aiken, South Carolina, The Proposed A-01 Outfall Constructed Wetlands at the Savannah River Site, FWS Log No. 4-6-98-258, June 1 .

Halverson, N. V., L. D., Wike, K. K. Patterson, J. A. Bowers, A. L. Bryan, K. F. Chen, C. L. Cummins, B. R. del Carmen, K. L. Dixon, D. L. Dunn, G. P. Friday, J. E. Irwin, R, K, Kolka, H. E. Mackey, Jr., J. J. Mayer, E. A. Nelson, M. H. Paller, V. A. Rogers, W. L. Specht, H. M. Westbury, and E. W. Wilde, 1997. SRS Ecology: Environmental Information Document, WSRC-TR-93-0223, Westinghouse Savannah River Company, Savannah River Site, Aiken, South Carolina.

Haselow, J. S., V. Price, D. E. Stephenson, H. W. Bledsoe, and B. B. Looney, 1989. Reactor Operation Environmental Information Document, Volume I: Geology, Seismology and Subsurface Hydrology (U), WSRC-89-815, Westinghouse Savannah River Company, Savannah River Site, Aiken, South Carolina.

HNUS (Halliburton NUS Environmental Corporation), 1997. Socioeconomic Characteristics of Selected Counties and Communities Adjacent to the Savannah River Site, June 1997, Halliburton NUS Corporation, Aiken, South Carolina.

Imm, D. W., and W. L. Jarvis, 1998. Biological Assessment for the Proposed A-01 Outfall Constructed Wetlands Project at the Savannah River Site, Savannah River Institute, U. S. Forest Service, New Ellenton, South Carolina.

Kadlec, R. H., and R. L. Knight, 1996. Treatment Wetlands, CRC Press, Boca Raton, Florida.

Lanier, T. H., 1996. Determination of the 100-Year Flood Plain on Upper Three Runs and Selected Tributaries, and the Savannah River at the Savannah River Site, South Carolina, 1995, Water-Resources Investigations Report 96-4014, U. S. Department of the Interior, U. S. Geological Surveys, Columbia, South Carolina. 
Mayer, J. J., and L. D. Wike, 1997. SRS Urban Wildlife: Environmental Information Document, WSRC-TR-97-0093, Westinghouse Savannah River Company, Savannah River Site, Aiken, South Carolina.

NUS Corporation, 1984. Floodplain/Wetlands Assessment of Forest Management Activities at the Savannah River Plant, SRC-84-8010/1, October 1984, NUS Corporation, Aiken, South Carolina.

Payne, W. L., 1996. Westinghouse Savannah River Company, Savannah River Site, Aiken, South Carolina, letter to M. G. Vickers, South Carolina Department of Health and Environmental Control, Columbia, South Carolina, Relocation of Outfall A-01 to Below a Natural Wetlands at SRS, April 2.

Payne, W. L., 1998. Westinghouse Savannah River Company, Savannah River Site, Aiken, South Carolina, letter to M. G. Vickers, South Carolina Department of Health and Environmental Control, Columbia, South Carolina, Corrected Mercury Value for A-01 Outfall NPDES Permit Application, February 19.

Rogers, V. A., 1990. Soil Survey of Savannah River Plant Area, Parts of Aiken, Barnwell, and Allendale Counties, South Carolina, U. S. Department of Agriculture, Soil Conservation Service, Aiken, South Carolina.

Sinicrope, T. L., R. Langis, R. M. Gersberg, M. J. Busnardo, and J. B. Zedler, 1992. Metals Removal by Wetland Mesocosms Subjected to Different Hydroperiods, Ecological Engineering, 1:309-322.

SRARP (Savannah River Archaeological Research Program), 1989. Archaeological Resource Management Plan of the Savannah River Archaeological Research Program, Savannah River Archaeological Research Program, South Carolina Institute of Archaeology and Anthropology, University of South Carolina, Aiken, South Carolina.

USGS (U. S. Geological Survey), 1988. Savannah River Plant, Department of Energy: 1987, U. S. Geological Survey, Reston, Virginia.

Wike, L. D., R. W. Shipley, A. L. Bryan, Jr., J. A. Bowers, C. L. Cummins, B. R. del Carmen, G. P. Friday, J. E. Irwin, J. J. Mayer, E. A. Nelson, M. H. Paller, V. A. Rogers, W. L. Specht, and E. W. Wilde, 1994. SRS Ecology: Environmental Information Document, WSRC-TR-93-496, Westinghouse Savannah River Company, Savannah River Site, Aiken, South Carolina.

WSRC (Westinghouse Savannah River Company), 1994a. Thirty-Year Solid Waste Generation Forecast by Treatability Group (U), WSRC-RP-94-584, Rev. 0, Westinghouse Savannah River Company, Savannah River Site, Aiken, South Carolina. 
WSRC (Westinghouse Savannah River Company), 1994b. Thirty-Year Solid Waste Generation Maximum and Minimum Forecast for SRS (U), WSRC-RP-94-585, Rev. 0, Westinghouse Savannah River Company, Savannah River Site, Aiken, South Carolina.

WSRC (Westinghouse Savannah River Company), 1997. Second Interim Progress Report on A-01 Outfall Studies Under NPDES Permit SC0000175, Special Condition I.B.1.b.(1)(b), Westinghouse Savannah River Company, Savannah River Site, Aiken, South Carolina. 
This page is intentionally left blank 


\section{APPENDIX A}

Floodplain/Wetlands Assessment

for

A-01 Outfall Constructed Wetlands Project at the

Savannah River Site 


\author{
Floodplain/Wetlands Assessment \\ for \\ A-01 Outfall Constructed Wetlands Project \\ at the \\ Savannah River Site
}

\title{
1.0 DESCRIPTION OF PROJECT
}

This Floodplain/Wetlands Assessment is prepared in compliance with 10 CFR Part 1022 as an Appendix to the Environmental Assessment for the A-01 Outfall Constructed Wetlands Project at the Savannah River Site (DOE/EA-1246). DOE proposes to construct and operate an artificial wetlands to treat effluent from the A-01 outfall located on the Savannah River Site (SRS). Since 1996, the A-01 effluent has consistently not met proposed new outfall limits which will become effective on October 1, 1999. DOE needs to reduce the copper and chronic toxicity levels in the effluent to ensure compliance when these proposed outfall limits go into effect. It has been determined that a subsurface flow wetlands would adequately treat the effluent to meet the new discharge limits. The overall proposed action entails the construction, and operation of the following: (1) a system of collection pipes, (2) a process water flow equalization basin and artificial subsurface flow wetland cell facility to treat the effluent from these outfalls, and (3) an outlet system to discharge the treated effluent through a relocated (i.e., downstream) A-01 outfall sampling point into waters of the State. As part of the proposed project activities, a new outfall structure would be constructed within the 100-year floodplain and wetlands associated with Tim's Branch, the headwaters stream into which the treated effluent would be discharged.

The construction of the new outfall structure at Tim's Branch would entail placement of an outflow pipe from the wetland cell facility downslope to the area adjacent to Tim's Branch, construction of an outfall structure on the margin of the stream channel, and placement of riprap within the streambed. The location the proposed new outfall would be on the south side of the Tim's Branch stream corridor. The pipeline right-of-way would be cleared. A temporary access road for construction vehicles would also be built within that right-of-way. The pipeline would either be installed above grade on support pillars or below grade until it reaches the outfall structure. Only the last few meters of this pipeline would be within the 100-year floodplain. The outfall structure would consist of a concrete headwall supporting the discharge pipe above the receiving stream. Large riprap would be placed within the wetlands of Tim's Branch at the outfall location to prevent erosion and scouring by the discharged effluent. A pedestrian path would be built between the parking area at the wetland cell facility and the outfall structure to provide readily-available and safe access for sampling activities. Stairs or steps leading down to a platform would be installed at the new NPDES compliance sampling point as deemed necessary. This access infrastructure would be within the 100-year floodplain, but not in the wetlands. 


\subsection{EFFECT ON FLOODPLAINS OR WETLANDS}

The proposed outfall structure would be installed in a portion of the Tim's Branch which is composed of both 100-year floodplain and jurisdictional waters/wetlands. At this project location, the 100-year floodplain is approximately 20-50 meters (65.6-164 feet) across the drainage corridor, while the wetlands habitat at that point are approximately 2-4 meters (6.7-13.1 feet) wide. The floodplain is periodically flooded, but not for periods sufficient to make it jurisdictional. The soils within the 100-year floodplain are Vaucluse-Ailey complex soils, which are well-drained, slowly permeable soils. The habitat type within this 100-year floodplain is a mixed hardwood, bottomland forest occupying a mesic headwater drainage basin. Predominant overstory species include loblolly pine (Pinus taeda), sweetgum (Liquidambar styraciflua), water oak (Quercus nigra), hackberry (Celtis laevigata), and hickory (Carya spp.). Further down from the location of the proposed outfall structure, sycamore (Platanus occidentalis) becomes a component of the overstory. The mid-story component in this area includes reproduction of the overstory and also includes American holly and wax myrtle (Myrica cerifera). Understory species include seedlings of the aforementioned species, with large areas of jasmine vines and lesser areas of greenbrier. Litter area of floodplain is predominantly intact. This reach of Tim's Branch is characterized by a stream channel which is deeply cut into the bottomland, with the streambed being situated approximately 1-3 meters (3.3-9.8 feet) below the grade of the surrounding forest floor. The lateral portions of the stream channel also exhibit erosional characteristics. The hydrology supporting this drainage system is provided through both the effluent from the local outfalls and storm water runoff from the surrounding higher elevation lands. The soils within the stream channel appear to be largely erosional sediment in composition. With the exception of the bases and roots of some overstory trees along the margins of the stream channel, the streambed is largely devoid of any floral species.

Temporary construction access in the 100-year floodplain of Tim's Branch will be required to install the new outfall structure. Operation of construction equipment in the floodplain areas will be minimized. Short-term impacts in floodplain areas will occur from the construction activities. Silt fences and other erosion control structures as needed will be installed to ensure no deposition in downslope areas. Erosional impacts would be expected to be small and temporary. Any merchantable timber would be salvaged and other vegetative cover removed from the 100 -year floodplain.

The only impacts to the wetlands would be in the form of the placement of the large riprap. This would be long-term, but should also minimize the scouring impacts realized by this outfall. Erosional impacts from the adjacent construction in the floodplain would be minimized through the use of silt fences along the margins of the stream channel.

The proposed activities associated with installing a new outfall structure are expected to fall under a U. S. Army Corps of Engineers Section 404 Nationwide Permit. Additionally, an erosion control plan will be developed in accordance with applicable 
State and local floodplain protection standards and followed to ensure that no additional impacts to wetlands will occur due to erosion and sedimentation. Best management practices will be employed during construction and maintenance activities.

\subsection{ALTERNATIVES CONSIDERED}

Alternatives to the proposed action are covered in Environmental Assessment for the A-01 Outfall Constructed Wetlands Project at the Savannah River Site (DOE/EA-1246). 


\section{APPENDIX B}

\section{Response to Public Comments}




\section{Table of Contents}

Number

Section I

Section II

L1

L2
Title

Page

Introduction

B-3

Public Comments and Responses

B-5

South Carolina Office of State Budget

B-6

U. S. Fish and Wildlife Service
B-18 


\section{Section I. Introduction}

In late January 1998, the Department of Energy (DOE) Savannah River Operations Office decided to initiate the preparation of an environmental assessment (EA) for the A-01 outfall constructed wetlands project at the Savannah River Site (SRS). This document preparation effort was implemented in compliance with the National Environmental Policy Act (NEPA) of 1969, as amended, the requirements of the Council on Environmental Quality Regulations for Implementing NEPA (40 CFR Parts 1500-1508), and the DOE Regulations for Implementing NEPA (10 CFR Part 1021). The assessment of environmental consequences of Federal actions that may affect the quality of the human environment are required under NEPA. Based on the potential for impacts described in the resultant document, DOE will either publish a Finding of No Significant Impact (FONSI) or prepare an environmental impact statement (EIS).

An initial internal scoping meeting was held on January 26, 1998, for this EA pursuant to the guidelines specified in the Savannah River Site NEPA Program Quality Assurance Plan: Preparation and Review of Environmental Assessments (U) (WSRC-RP-97-010). The proposed action, alternatives, specific assessment studies needed, project time frame, and public participation were discussed at that meeting. Preparation of the preliminary draft EA was begun on January 27, 1998. Notification was sent to the States of South Carolina and Georgia on January 27, 1998, regarding DOE's intent to prepare this EA. On February 26, 1998, a notice was published in the SRS Environmental Bulletin announcing to the general public DOE's intent to prepare this EA. Pursuant to 10 CFR Part 1022, the DOE Floodplain and Wetlands involvement notification for the proposed action was published in the March 3, 1998, issue of the Federal Register (Vol. 63, No. 41). The preliminary draft EA was completed by the middle of March 1998. As required in 10 CFR Part 1021, the predecisional draft EA was transmitted to the States of South Carolina and Georgia on March 17, 1998, for review and comment. The associated State comment period, scheduled for 14-30 days as per DOE NEPA regulations, began on March 24, 1998, the date of receipt of the draft EA transmittal package by both States. In early April of 1998, the availability of the predecisional draft EA for the proposed action was announced in the April 13, 1998, issue of the SRS Environmental Bulletin, which had been distributed to several thousand stakeholders in both South Carolina and Georgia, including Federal, State, and local agencies, government officials, and members of environmental interest groups as well as interested citizens. Seven copies of the predecisional draft EA were requested for review as a result of this announcement. A total of seven responses were received, ranging in length from one to two pages. Agency responses numbered seven. None were provided by individual stakeholders.

The remainder of this appendix is contained in one section. That section (i.e., Section II) presents the unedited text of all letters received and the direct response to each question or comment raised or references another location where the issue has already been addressed in the EA. 


\section{Section II. Response to Public Comments}

STATE OF SOUTH CAROLNA

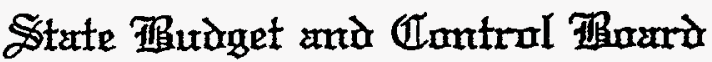 \\ OFFICE OF STATE BUDGET}
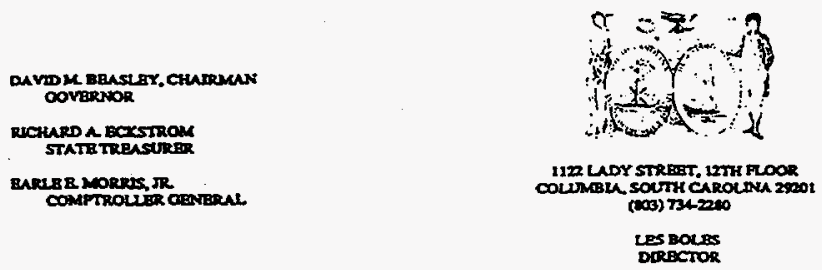

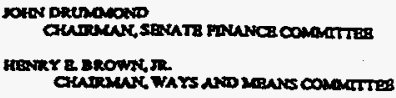

EOSCUTIVB DTRECTOR

June 10, 1998

Mr. Andrew R. Grainger

NEPA Compliance Officer

Engineering and Analysis Division

Savannah River Operations Office - P. O. Box A

Aiken, South Carolina 29802

Project Name: Draft Environmental Assessment (EA) for the A-01 Outfall Constructed Wetlands at the Savannah River Site (DOE/EA-1246).

Project Number: EIS-980304-004

Dear Mr. Grainger,

The Office of State Budget, has conducted an intergovernmental review on the above referenced activity as provided by Presidential Executive Order 12372 All comments received as a result of the review are enclosed for your use.

The State Application Identifier number indicated above should be used in any future correspondence with this office. If you have any questions call me at (803) 734-0485.

Sincerely,

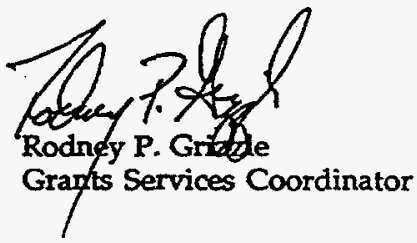

Enclosures

Comment L1. Page 1 of 8. 


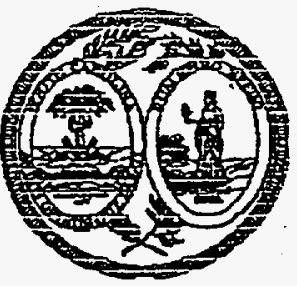

Nancy Brock

\section{Office of State Budget}

South Carolina Project Notification and Review

1122 Lady Street, 12th floor

Columbia, SC 29201

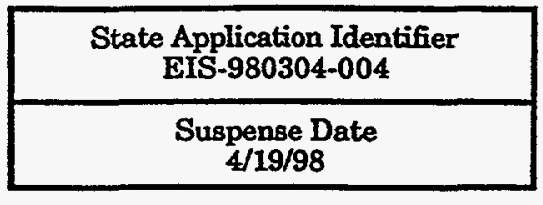

South Carolina Department

The Office of State Budget is authorized to operate the South Carolina Project Notification and Review System (SCPNRS). Through the system the appropriate state and local officials are given the opportunity to review, comment, and be involved in efforts to obtain and use federal assistance, and to assess the relationship of proposals to their plans and programs.

Please review the attached information, mindful of the impact it may have on your agency's goals and objectives. Document the results of your review in the space provided. Return your response to us by the suspense date indicated above. Your comments will be reviewed and utilized in making the official state recommendation concerning the project. The recommendation will be forwarded to the cognizant federal agency.

\section{Should you have no comment, please return the form sigactand \\ If you have any questions, call me at (803) 734-0485.

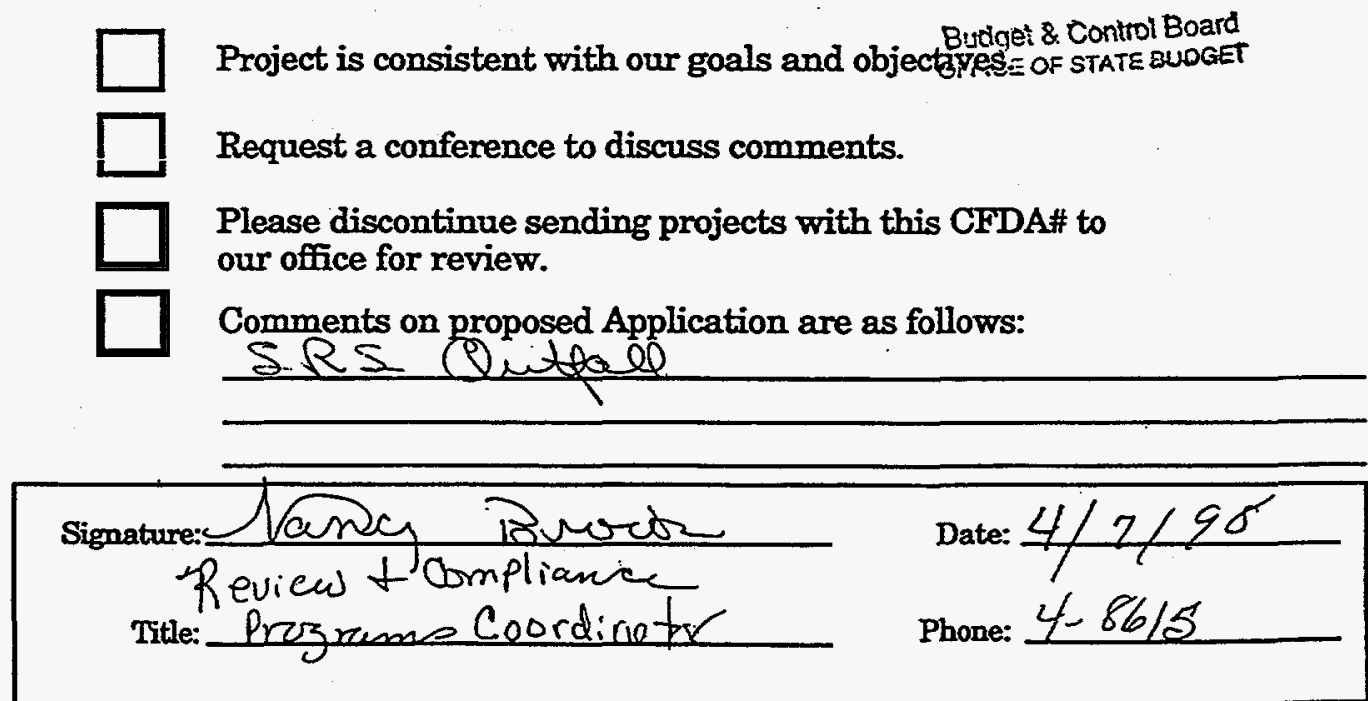

Comment L1. Page 2 of 8 . 


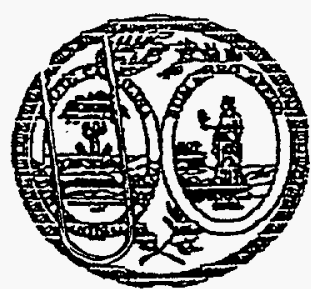

\section{Office of State Budget} South Carolina Project Notification and Review

1122 Lady Street, 12th floor Columbia , SC 29201

\begin{tabular}{|c|}
\hline $\begin{array}{c}\text { State Application Identifier } \\
\text { EIS-980304-004 }\end{array}$ \\
\hline Suspense Date \\
$4 / 19 / 98$ \\
\hline
\end{tabular}

Joel T. Cassidy

South Carolina Employment Security Commission

The Office of State Budget is authorized to operate the South Carolina Project Notification and Review System (SCPNRS). Through the system the appropriate state and local officials are given the opportunity to review, comment, and be involved in efforts to obtain and use federal assistance, and to assess the relationship of proposals to their plans and programs.

Please review the attached information, mindful of the impact it may have on your agency's goals and objectives. Document the results of your review in the space provided. Return your response to us by the suspense date indicated above. Your comments will be reviewed and utilized in making the official state recommendation concerning the project. The recommendation will be forwarded to the cognizant federal agency.

Should you have no comment, please return the form signed agd dated.

If you have any questions, call me at (803) 734-0485.

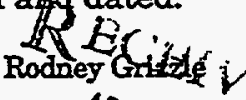

$\square$

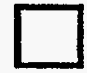

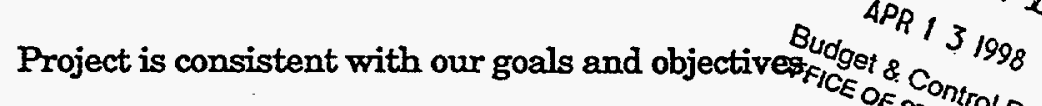

Request a conference to discuss comments.

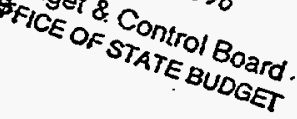

Please discontinue sending projects with this CFDA\# to

our office for review.

$\square$ Comments on proposed Application are as follows:

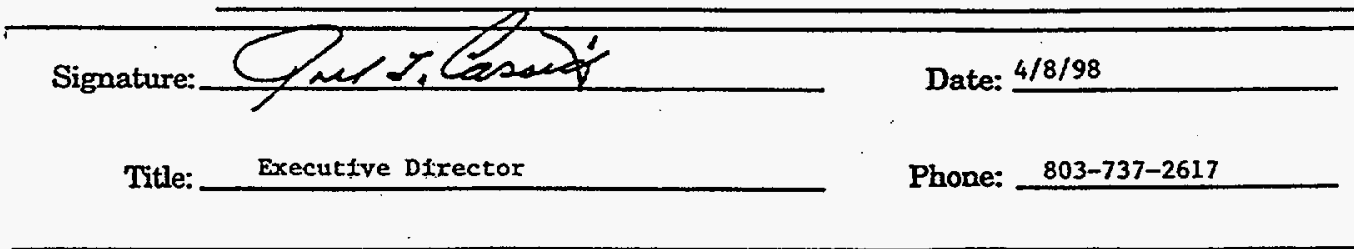

Comment L1. Page 3 of 8. 


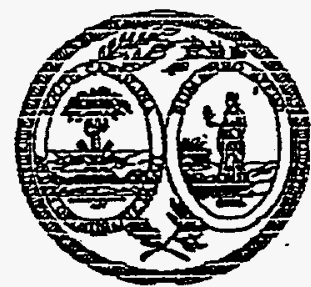

Office of State Budget

South Carolina Project Notification and Review

1122 Lady Street, 12th floor

Columbia , SC 29201

\begin{tabular}{|c|}
\hline $\begin{array}{c}\text { State Application Identifier } \\
\text { EIS-980304-004 }\end{array}$ \\
\hline Suspense Date \\
4/19/98 \\
\hline
\end{tabular}

George Bistany

South Carolina Department of Commerce

The Office of State Budget is authorized to operate the South Carolina Project Notification and Review System (SCPNRS). Through the system the appropriate state and local officials are given the opportunity to review, comment, and be involved in efforts to obtain and use federal assistance, and to assess the relationship of proposals to their plans and programs.

Please review the attached information, mindful of the impact it may have on your agency's goals and objectives. Document the results of your review in the space provided. Return your response to us by the suspense date indicated above. Your comments will be reviewed and utilized in making the official state recommendation concerning the project. The recommendation will be forwarded to the cognizant federal agency.

Should you have no comment, please return the form signed and dated.

If you have any questions, call me at (803) 734-0485.

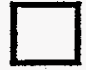

$\square$

Project is consistent with our goals and objectives.

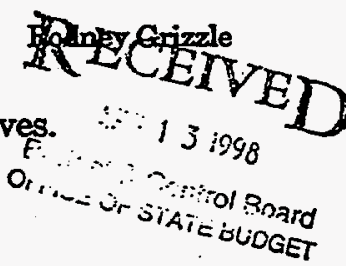

Request a conference to discuss comments.

Please discontinue sending projects with this CFDA\# to our office for review.

Comments on proposed Application are as follows:

Signature:

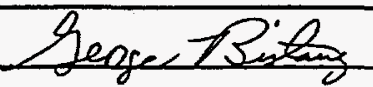

Date:

$4-q-q f$

Title:

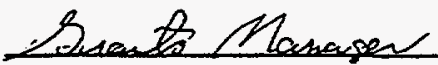

Phone: 734- OLS

Comment L1. Page 4 of 8. 


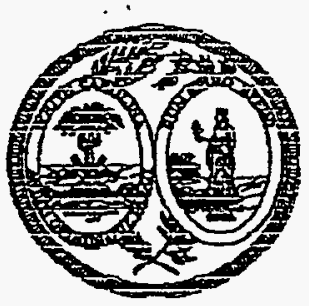

\section{Office of State Budget}

South Carolina Project Notification and Review

1122 Lady Street, 12th floor

Columbia , SC 29201

\begin{tabular}{|c|}
\hline $\begin{array}{c}\text { State Application Identifier } \\
\text { EIS-980304-004 }\end{array}$ \\
\hline $\begin{array}{c}\text { Suspense Date } \\
\text { 4/19/98 }\end{array}$ \\
\hline
\end{tabular}

Dr. Paul A. Sandifer

South Carolina Natural Resources Department

The Office of State Budget is authorized to operate the South Carolina Project Notification and Review System (SCPNRS). Through the system the appropriate state and local officials are given the opportunity to review, comment, and be involved in efforts to obtain and use federal assistance, and to assess the relationship of proposals to their plans and programs.

Please review the attached information, mindful of the impact it may have on your agency's goals and objectives. Document the results of your review in the space provided. Return your response to us by the suspense date indicated above. Your comments will be reviewed and utilized in making the official state recommendation concerning the project. The recommendation will be forwarded to the cognizant federal agency.

Should you have no comment, please return the form signed and dated.

If you have any questions, call me at (803) 734-0485. Rodney Grizle

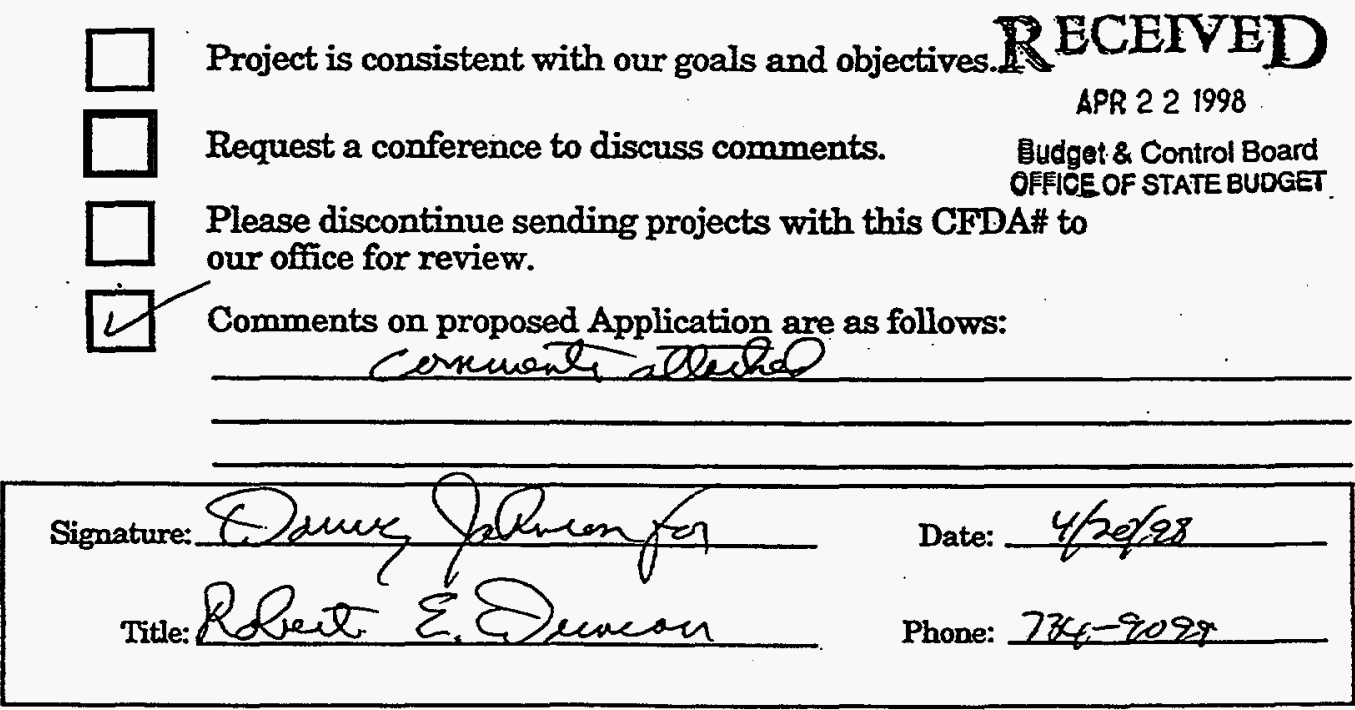

Comment L1. Page 5 of 8 . 


\section{South Carolina Department of Natural Resources}

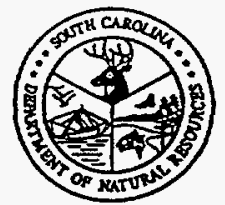

April 20, 1998

Paul A. Sandifer, Ph.D. Director

Ms. Omeagia Burgess

Office of State Budget

1122 Lady Street

$12^{\text {th }}$ Floor

Columbia, S.C. 29201

REF: EIS-980304-004; Department of Energy; Savannah River Site

Dear Ms. Burgess:

Personnel with the South Carolina Department of Natural Resources have reviewed the above referenced project and evaluated its impact on wildlife and fisheries habitat, wetlands, floodplains, water quality, recreation and other factors relating to the conservation of natural resources.

We believe that the proposed project may have adverse impacts to natural resources and offer the following recommendations.

1) Prior to beginning any land disturbing activity, appropriate erosion control measures, such as silt fences, silt bariers or other devices, must be placed between the disturbed area and the affected waterway or wetland; and maintained in a functioning capacity until the area is permanently stabilized.

2) All necessary measures must be taken to prevent oil, tar, trash and other pollutants from entering the adjacent offsite areas.

3) Once the project is initiated, it must be carried to completion in an expeditious manner in order to minimize the period of disturbance to the environment.

4) Upon project completion, all disturbed areas must be permanently stabilized with vegetative cover, rip-rap or other erosion control methods as appropriate.

5) Land disturbing activities must avoid to the greatest extent possible, encroachment into any wetland areas. Wetlands that are unavoidably impacted must be appropriately mitigated.

Comment L1. Page 6 of 8 . 
Page 2

EIS-980304-004; Department of Energy

April 20, 1998

6) Construction activities in Tim's Branch must be minimized during the months of March, April, May and June because of potential impacts to fish spawning.

7) The proposed project, including any necessary conditions and restrictions, must not result in degradation of existing water quality as determined by the South Carolina Department of Health and Environmental Control.

8) This project must be in compliance with Executive Order 11988 regarding evaluation of flood hazards in floodplains.

We offer no objection to the proposed project, provided that project plans are conditioned to reflect the above recommendations nno concerns.

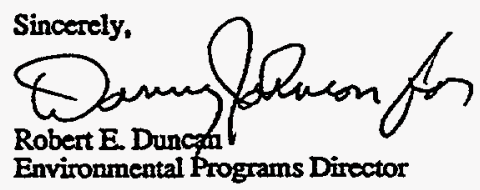

Comment L1. Page 7 of 8 . 


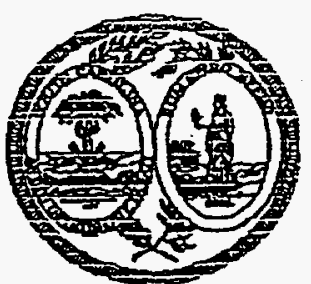

Stan M. MaKinney Office of the Adjutant General

\section{Office of State Budget}

South Carolina Project Notification and Review

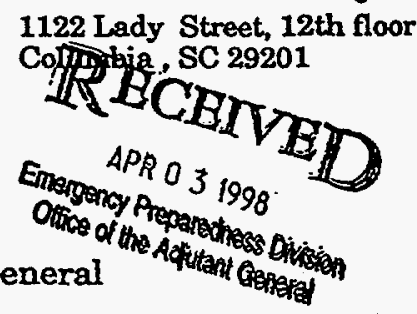

The Office of State Budget is authorized to operate the South Carolina Project Notification and Review System (SCPNRS). Through the system the appropriate state and local officials are given the opportunity to review, comment, and be involved in efforts to obtain and use federal assistance, and to assess the relationship of proposals to their plans and programs.

Please review the attached information, mindful of the impact it may have on your agency's goais and objectives. Document the results of your review in the space provided. Return your response to us by the suspense date indicated above. Your comments will be reviewed and utilized in making the official state recommendation concerning the project. The recommendation will be forwarded to the cognizant federal agency.

Should you have no comment, please return the form signed and defo If you have any questions, call me at (803) 734-0485.

$x$ Project is consistent with our goals and objective Budget \& CONICE OF STATE BUDGET

Request a conference to discuss comments.

Please discontinue sending projects with this CFDA\# to our office for review.

Comments on proposed Application are as follows:

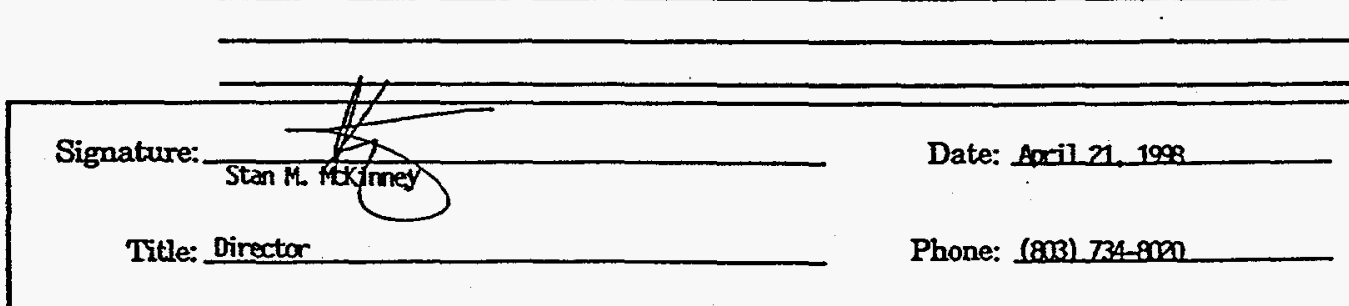

Comment L1. Page 8 of 8 . 


\section{Responses to Comments of Draft EA - Letter L1}

\section{Response to Comment L1-01}

As discussed in both Section 2.1 and Appendix A of the EA, specific erosion control and storm water management practices would be employed to ensure that there is no deposition of erosional material or sediment into the downslope wetland areas during construction.

\section{Response to Comment L1-02}

Only minor amounts of debris and rubble are expected to be generated during the construction of the proposed facility. This material would be removed from the construction site prior to completion of this phase of the project implementation.

There would be a potential for petroleum hydrocarbon spills due to mechanical breakdown of equipment and leaks from vehicles during the construction phase of the project. The potential for such spills to affect offsite areas would be small because such spills would be isolated events, incapable of penetrating SRS soils sufficiently to reach the groundwater. In addition, standard operating procedures call for excavation of isolated pockets of contaminated soil for onsite treatment using approved techniques, or for transport off of SRS to appropriate disposal facilities.

\section{Response to Comment L1-03}

Because of the regulatory compliance basis for the proposed action, the implementation of the project would be undertaken in an expeditious manner, which would minimize any impacts to the environment.

\section{Response to Comment L1-04}

As discussed in both Section 2.1 and Appendix A of the EA, disturbed areas would be stabilized (e.g., through either seeding or the placement of rip rap) to prevent any impacts due to erosion.

\section{Response to Comment L1-05}

As discussed in Appendix A of the EA, wetlands impacts would be minimized. The only impact to the local wetlands would in the form of placement of riprap within the eroded channel of Tim's Branch. This impact would be long-term, but would also minimize the potential scouring impacts as a result of effluent being discharged through the project's outfall. Any project activities that would impact wetlands would be permitted through Section 404 of the Clean Water Act, including the implementation of any mitigation required. 


\section{Response to Comment L1-06}

The best management practices to be employed during the construction phase of the proposed project would minimize any potential impacts to local fish populations (including during spawning). Because of the chronic toxicity problem in Tim's Branch (which the proposed action would be correcting), there are no macroinvertebrate or fish populations found in the upper reaches of Tim's Branch in the immediate area of the project location. Approximately one-half to three-quarters of a mile below the proposed project location, infrequent observations of mosquitofish (Gambusia affinis) and small shiners (Notropis spp.) have been made. Below that location, there are two physical barriers (i.e., the culverted road-crossing at SRS Road D-2 and the Steed Pond dam) which would prevent upstream access by any fish present in the lower reaches of this drainage.

\section{Response to Comment L1-07}

The purpose of the proposed project is to improve the water quality in Tim's Branch. No aspect of the proposed action would be expected to result in the degradation of water quality in this drainage corridor.

\section{Response to Comment L1-08}

Pursuant to the DOE regulations for compliance with floodplain/wetlands environmental review requirements (10 CFR Part 1022), the proposed action would be in compliance with Executive Order 11988 (i.e., Floodplain Management). Please refer to Appendix A of the EA for more details on this regulatory compliance issue. 


\title{
United States Department of the Interior
}

\author{
FISH AND WILDLIFE SERVICE \\ P.O. Box 12559 \\ 217 For Johnson Road \\ Charieston, South Carolina 29422-2559
}

June 1,1998

Mr. Stephen A. Danker

Engineering and Analysis Division

Department of Energy

Savannah River Operations Office

P.O. Box A

Aiken, South Carolina 29802

Re: The Proposed A-01 Outfall Constructed Wetlands at the Savannah River Site FWS Log No. 4-6-98-258

Dear Mr. Danker:

Personnel of the U.S. Fish and Wildlife Service (Service) have reviewed the letter, Biological Assessment (BA) and Ecological Assessment received on May 7, 1998 concerning the abovereferenced project in Aiken County, South Carolina. The following comments are provided in accordance with the Fish and Wildlife Coordination Act, as amended (16 U.S.C. 661-667e), and Section 7 of the Endangered Species Act (ESA), as amended (16 U.S.C. 1531-1543).

The proposed project consists of the construction and operation of wetlands to treat effluent discharges from the A-01 outfall at the Savannah River Site. The project would eliminate 15-16 acres of planted pine habitat and the filling of 0.3 acres of wetland. The project is to be conducted to treat A- 01 outfall waters prior to their discharge to the environment

The construction of the facility could lead to the loss of 15-16 acres of potential foraging habitat for the red-cockaded woodpecker (Picoides borealis) (RCW). RCWs nest in living pines that are $\geq 60$ years of age and forage in pines $\geq 30$ years in age. Although this habitat would be permanently lost we do not feel that RCWs will be impacted by the proposed activity due to the relatively small size of the construction site, the proximity of the construction site to other industrial areas, the absence of RCWs in the area and the distance of the nearest RCW group from the site.

Comment L2. Page 1 of 2. 
Other wildlife may be attracted to the area during operation due to its wetland appearance. Since the area will contain elevated levels of certain contaminants we suggest that animal deterrents be implemented to minimize exposure of wildlife to these contaminants. We also suggest that any wildlife that is found within the site during operation, be removed from the site and relocated to an appropriate habitat.

Based on the information received, we will concur with a determination that this action is not likely to adversely affect federally listed or proposed endangered and threatened species. In view of this, we believe that the requirements of Section 7 of the Endangered Species Act have been satisfied. However, obligations under Section 7 of the Act must be reconsidered if (1) new information reveals impacts of this identified action that may affect listed species or critical habitat in a manner not previously considered, (2) this action is subsequently modified in a manner which was not considered in this assessment, or (3) a new species is listed or critical habitat is determined that may be affected by the identified action.

Your interest in ensuring the protection of endangered and threatened species and our nation's valuable wetland resources is appreciated. If you have any questions please contact Mr. Rusty Jeffers at (803) 727-4707 ext. 20 of my staff. In future correspondence concerning the project, please reference FWS Log No. 4-6-98-258.

\author{
Sincerely yours,

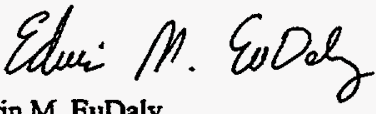 \\ Edwin M. EuDaly \\ Acting Field Supervisor
}

EME/RJ/LD

Comment L2. Page 2 of 2. 


\section{Responses to Comments of Draft EA - Letter L2}

\section{Response to Comment L2-01}

As discussed in both Section 4.1 of the EA, the proposed facility should be monitored during its operational life for any potential impacts to any vertebrates inhabiting this artificial aquatic habitat. Although still undecided at present, the placement of a perimeter fence with metal sheeting secured to its base would function to exclude a number of potential wildlife species from colonizing this facility. Daily human activity should further serve to discourage occupation or extended use of the site by species of either waterfowl or wading birds. Infrequent foraging by larger vertebrate scavengers and predators [e.g., raccoon (Procyon lotor), American alligator (Alligator mississippiensis), or common snapping turtle (Chelydra serpentina) would be difficult to either discourage or prevent. As in the case of other artificial basins on site, any of these species which may either take up residence in or become destructive to this facility would be live-trapped and removed by the SRS animal control subcontractor. 